\title{
Seismic study of the transform-rifted margin in Davis Strait between Baffin Island (Canada) and Greenland: What happens when a plume meets a transform
}

\author{
Thomas Funck, ${ }^{1,2}$ H. Ruth Jackson, ${ }^{3}$ Keith E. Louden, ${ }^{4}$ and Frauke Klingelhöfer ${ }^{5}$
}

Received 24 January 2006; revised 25 July 2006; accepted 21 November 2006; published 6 April 2007.

[1] The Davis Strait transform margin was studied using a 630-km-long wide-angle reflection/refraction seismic transect extending from SE Baffin Island to Greenland. Dense airgun shots were recorded by 28 ocean bottom seismometers deployed along the line. A $P$ wave velocity model was developed from forward and inverse modeling of the wide-angle data and incorporation of coincident deep multichannel reflection seismic data. Off Baffin Island in the Saglek Basin, 7 to 11-km-thick two-layered continental crust $(5.8-6.6 \mathrm{~km} / \mathrm{s})$ is observed. Off Greenland, continental crust is divided into three layers $(5.4-6.8 \mathrm{~km} / \mathrm{s})$ with a maximum thickness of $20 \mathrm{~km}$. Farther offshore Greenland the crust thins to $7-12 \mathrm{~km}$ and the lower crust disappears. Between the continental blocks a $140-\mathrm{km}$-wide zone with oceanic crust (layer 2 is $5.4-6.2 \mathrm{~km} / \mathrm{s}$ and layer 3 is $6.7-7.0 \mathrm{~km} / \mathrm{s}$ ) is located. The western half of this zone is interpreted to be part of a volcanic margin with seaward dipping reflectors; the eastern part is associated with the Ungava fault zone (UFZ), the major transform fault in Davis Strait. The UFZ thus acted as leaky transform fault during phases of transtension. Southward flow of material from the Iceland plume created a 4 to 8 -km-thick underplated layer $(7.4 \mathrm{~km} / \mathrm{s})$ beneath the thinned portions of the continental crust and beneath previously emplaced oceanic crust. Plume related Paleogene volcanism is indicated by an up to 4-km thick layer $(4.3-5.8 \mathrm{~km} / \mathrm{s})$ with basalts and interbedded sediments that can be traced from SE Baffin Island $400 \mathrm{~km}$ toward the east.

Citation: Funck, T., H. R. Jackson, K. E. Louden, and F. Klingelhöfer (2007), Seismic study of the transform-rifted margin in Davis Strait between Baffin Island (Canada) and Greenland: What happens when a plume meets a transform, J. Geophys. Res., 112, B04402, doi:10.1029/2006JB004308.

\section{Introduction}

[2] The transform-rifted margin in Davis Strait links Labrador Sea to the south with Baffin Bay to the north (Figure 1). The Davis Strait region is of major scientific interest because Paleocene volcanic rocks in that area were among the first products of the Iceland mantle plume [Storey et al., 1998]. Volcanic margins are observed in the Davis Strait, whereas nonvolcanic margins are observed farther south in Labrador Sea [Chian et al., 1995b; Funck and Louden, 1999] and southwest Greenland [Chian and Louden, 1994]. This poses fundamental questions regarding the lateral extent and distribution mechanisms of plume material. Knowledge of the

\footnotetext{
${ }^{1}$ Danish Lithosphere Centre, Copenhagen, Denmark.

${ }^{2}$ Now at Geological Survey of Denmark and Greenland (GEUS), Copenhagen, Denmark.

${ }^{3}$ Geological Survey of Canada (Atlantic), Bedford Institute of Oceanography, Dartmouth, Nova Scotia, Canada.

${ }^{4}$ Department of Oceanography, Dalhousie University, Halifax, Nova Scotia, Canada.

${ }^{5}$ Department of Geodynamics and Geophysics, IFREMER, Plouzané, France.
}

Copyright 2007 by the American Geophysical Union. 0148-0227/07/2006JB004308\$09.00 crustal structure in Davis Strait is the key to understanding the interaction of a plume with a transform-rifted margin. However, the interpretation of existing refraction/wide-angle reflection seismic data has been controversial.

[3] A seismic refraction profile in the central part of Davis Strait (line D1 of Keen and Barrett [1972]; for location see Figure 2) that showed a total crustal thickness of over $20 \mathrm{~km}$ was interpreted as thick oceanic crust, similar to the crust beneath Iceland. Later, Keen et al. [1974] suggested that this crust could also be the result of plumerelated volcanic rocks mixed with fragments of continental crust. This uncertainty of continental versus oceanic composition continues in the literature. Tucholke and Fry [1985] show in their map of basement structure in the NW Atlantic Ocean that large portions of Davis Strait are underlain by oceanic crust. In contrast, Chalmers and Pulvertaft [2001] argue for continental crust in central Davis Strait primarily based on seismic reflection records and age information from drilled sediments. Determination of the crustal structure in Davis Strait is also an important constraint for plate reconstructions between North America and Greenland, another controversial subject in terms of when the seafloor spreading in the Labrador Sea initiated [Roest and Srivastava, 1989; Chalmers and Laursen, 1995]. 


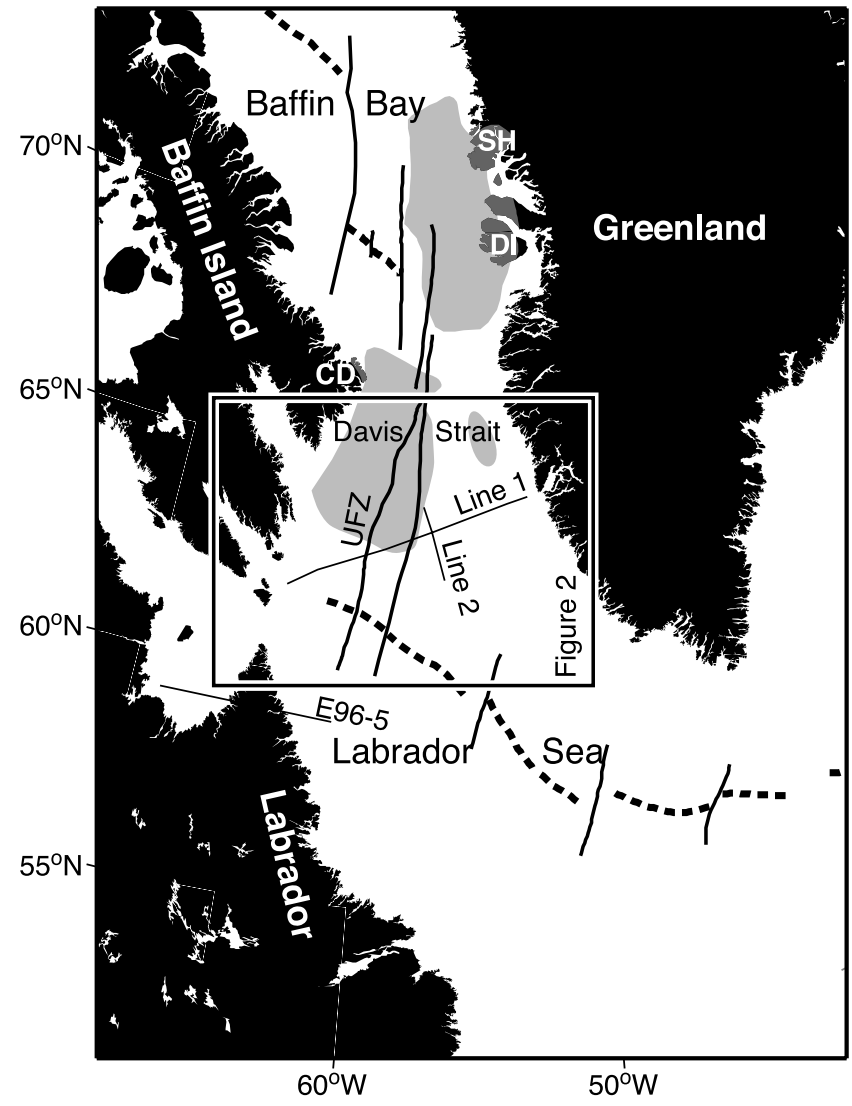

Figure 1. Location map of the Davis Strait region. Thin solid lines show the location of the NUGGET refraction seismic experiment (lines 1 and 2, this study) and of line E96-5 [Funck and Louden, 1999]. Solid lines indicate faults and fracture zones. Dashed lines show the position of the extinct spreading axis in Labrador Sea and Baffin Bay. Shaded regions (light gray) outline offshore areas with Paleogene basalts (after Oakey et al. [2001b, 2001c]), onshore volcanics are shown in dark gray (after Escher and Pulvertaft [1995]). Abbreviations are CD, Cape Dyer; DI, Disko Island; SH, Svartenhuk Halvø; UFZ, Ungava fault zone.

[4] To determine the crustal composition in Davis Strait, the NUGGET (Nunavut to Greenland Geophysical Transect) refraction seismic experiment was carried out in the southern part of the strait in 2003. In this paper, results from the east-west transect (line 1, Figure 2) are presented. This line crosses four deep wells and is coincident with a multichannel seismic (MCS) line collected in 2001 by the geophysical company TGS-NOPEC, who made the data available to us to aid in analyzing the refraction seismic data.

\section{Geological Setting}

[5] Davis Strait is a bathymetric high between Baffin Island to the west and Greenland to the east (Figure 1) that separates Labrador Sea from Baffin Bay. The oldest undisputed sea-floor spreading magnetic anomaly in Labrador Sea (Figure 2) is magnetic chron 27 (61.3-60.9 Ma) [Chalmers and Laursen, 1995]. Other authors suggest that sea-floor spreading started during magnetic chron 33 (79.7-74.5 Ma) [Roest and Srivastava, 1989] or between chron 29 and 31 (66-64 Ma) [Chian et al., 1995a]. A reorientation of the spreading axis took place during magnetochron $24 \mathrm{r}(55.9-53.3 \mathrm{Ma})$, at the same time as sea-floor spreading started between Greenland and Europe, and then ceased by magnetochron 13 (33 Ma) [Srivastava, 1978].

[6] Baffin Bay is the northwest extension of the Labrador Sea spreading system. The transform margin in Davis Strait that links these two rift axes is characterized by the Ungava transform fault, a name that was first introduced by Kerr [1967]. Later, the term Ungava fault zone (UFZ) became more commonly used (Figures 1 and 2). The position of the UFZ is taken to be along the SE side of a line of striking positive gravity anomalies. Davis Strait, unlike Labrador Sea and Baffin Bay, is bounded by volcanic margins. Onshore, Palaeogene volcanics crop out on either side of the strait in a short narrow belt near Cape Dyer on Baffin Island and in a wider zone in the Disko-Svartenhuk area of West Greenland (Figure 1). Storey et al. [1998] identified two pulses of volcanism in West Greenland: one between 60.7 and $59.4 \mathrm{Ma}$ and one between 54.8 and 53.6 Ma. The first pulse is probably related to the arrival of the GreenlandIceland plume. Larsen and Saunders [1998] explain the almost simultaneous volcanism from 62 to $60 \mathrm{Ma}$ in West Greenland [Storey et al., 1998], East Greenland [Larsen and Saunders, 1998], and on the British Isles [Pearson et al., 1996] by rapid lateral flow of a small plume head that impinged on the continental lithosphere. Continental breakup of East Greenland from NW Europe occurred at $56 \mathrm{Ma}$ [Larsen and Saunders, 1998] and caused a reorientation of the spreading axis in Labrador Sea [Srivastava, 1978]. Storey et al. [1998] suggested that the second pulse of volcanism in West Greenland could be related to this reorientation of the spreading axis, during which remnants of the plume could have generated melts along the UFZ. Volcanics, lava flows and seaward dipping reflectors are mapped in large areas of Davis Strait [Skaarup et al., 2006; Chalmers and Laursen, 1995; Chalmers, 1997]. In addition, volcanics were drilled in the Hekja O-71 [Klose et al., 1982], Ralegh N-18 (BASIN database, Geological Survey of Canada, Dartmouth, Nova Scotia, Canada), and Gjoa G-37 [Klose et al., 1982] wells (Figure 2). Laser Argon dating on basaltic rocks of the Gjoa well yielded ages of 59.5 Ma [Williamson et al., 2001], which relates those rock samples to the first pulse of volcanism.

[7] The NUGGET refraction seismic experiment was designed to map the volcanics in the southern Davis Strait area and see how they relate to deeper crustal structure and if they are associated with plume-related magmatic underplating. However, the resolution of the refraction seismic data and the few available dates on the offshore volcanics make it difficult to distinguish between the two volcanic pulses separated by only $4 \mathrm{~m}$.y. The crustal composition (oceanic versus continental) in Davis Strait and across the transform margin was addressed by line 1, while line 2 (not part of this paper) is concerned with the character of the continent-ocean transition zone in northern Labrador Sea and the initiation of seafloor spreading.

\section{Wide-Angle Seismic Experiment}

\subsection{Data Acquisition and Processing}

[8] The NUGGET refraction seismic experiment was carried out in August 2003 onboard the Canadian Coast 


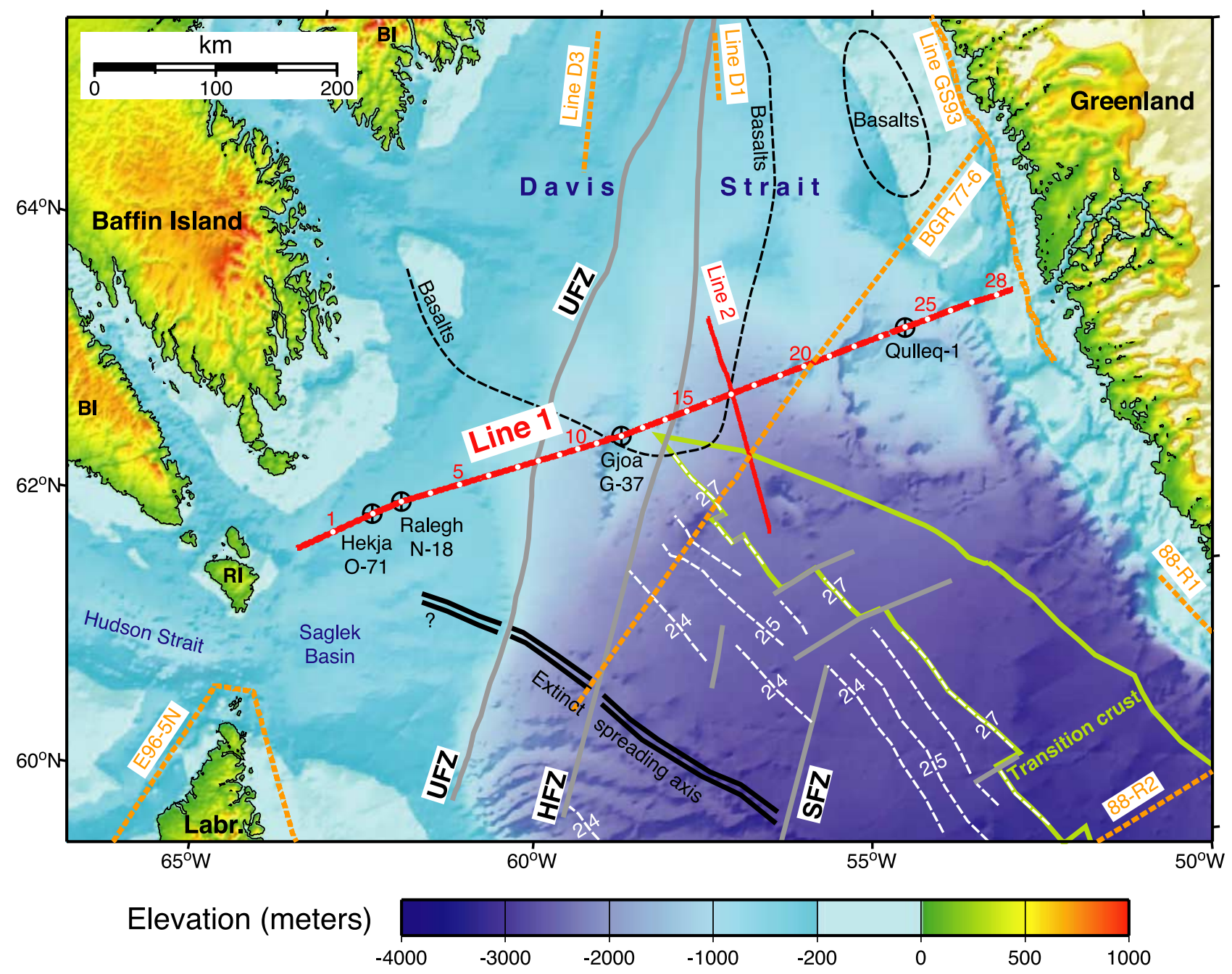

Figure 2. Physiographic map of the study area. The elevation model [Oakey et al., 2001a] is shaded by artificial illumination from the southeast. Red solid lines show the location of the NUGGET refraction seismic experiment. Positions of ocean bottom seismometers are marked by open circles, numbers indicate the station number. Circles filled with crosses mark the position of deep exploration wells along line 1. Dashed lines show offshore areas with Paleogene basalts (after Oakey et al. [2001b, 2001c]) and the green line marks transitional crust (modified after Chalmers and Pulvertaft [2001]). Solid gray lines indicate faults and fracture zones. White dashed lines show the position of sea-floor spreading anomalies 27 and younger (after Roest and Srivastava [1989]). Other seismic experiments are shown by dashed orange lines: line D1 [Keen and Barrett, 1972], line D3 [Srivastava et al., 1982], 88-R1 [Chian and Louden, 1992], line GS93 [Gohl and Smithson, 1993], 88-R2 [Chian and Louden, 1994], E96-5N [Funck et al., 2000], BGR77-6 [Chalmers and Laursen, 1995]. Elevation data are taken from Oakey et al. [2001a]. Abbreviations are BI, Baffin Island; HFZ, Hudson fracture zone; Labr., Labrador; RI, Resolution Island; SFZ, Snorri fracture zone; UFZ, Ungava fault zone.

Guard ship Hudson [Jackson et al., 2003]. Line 1 is a 630-km-long East-West transect in southern Davis Strait/ northern Labrador Sea (Figure 2). It links four deep wells: Hekja O-71 (4566 m below rotary table), Ralegh N-18 (3858 m), Gjoa G-37 (3998 m), and Qulleq-1 (2973 m). The line also coincides with reflection seismic line GreenCan 2001-12A collected by TGS-NOPEC using a 6-km-long streamer with 480 channels. Record length was $8 \mathrm{~s}$.

[9] For the refraction seismic experiment a total of 30 ocean bottom seismometers (OBS) were deployed at 28 sites (Figure 2). At sites 1 and 2 there were two OBS deployments each for an instrument test. Both Ifremer
(Institut français de recherche pour l'exploitation de la mer; sites 6 through 12 and 21 through 28) and the instrument pool of the Geological Survey of Canada and Dalhousie University provided 15 OBS each. All instruments were equipped with a hydrophone and with threecomponent $4.5-\mathrm{Hz}$ geophones. The positions of the OBS were chosen to achieve adequate coverage of structures that were recognized in the MCS data, resulting in a variable station spacing between 16 and $36 \mathrm{~km}$. OBS 5 could not be recovered at the end of the experiment.

[10] The seismic source was a tuned airgun array that consisted of 12 guns with a total volume of $104 \mathrm{~L}$. 


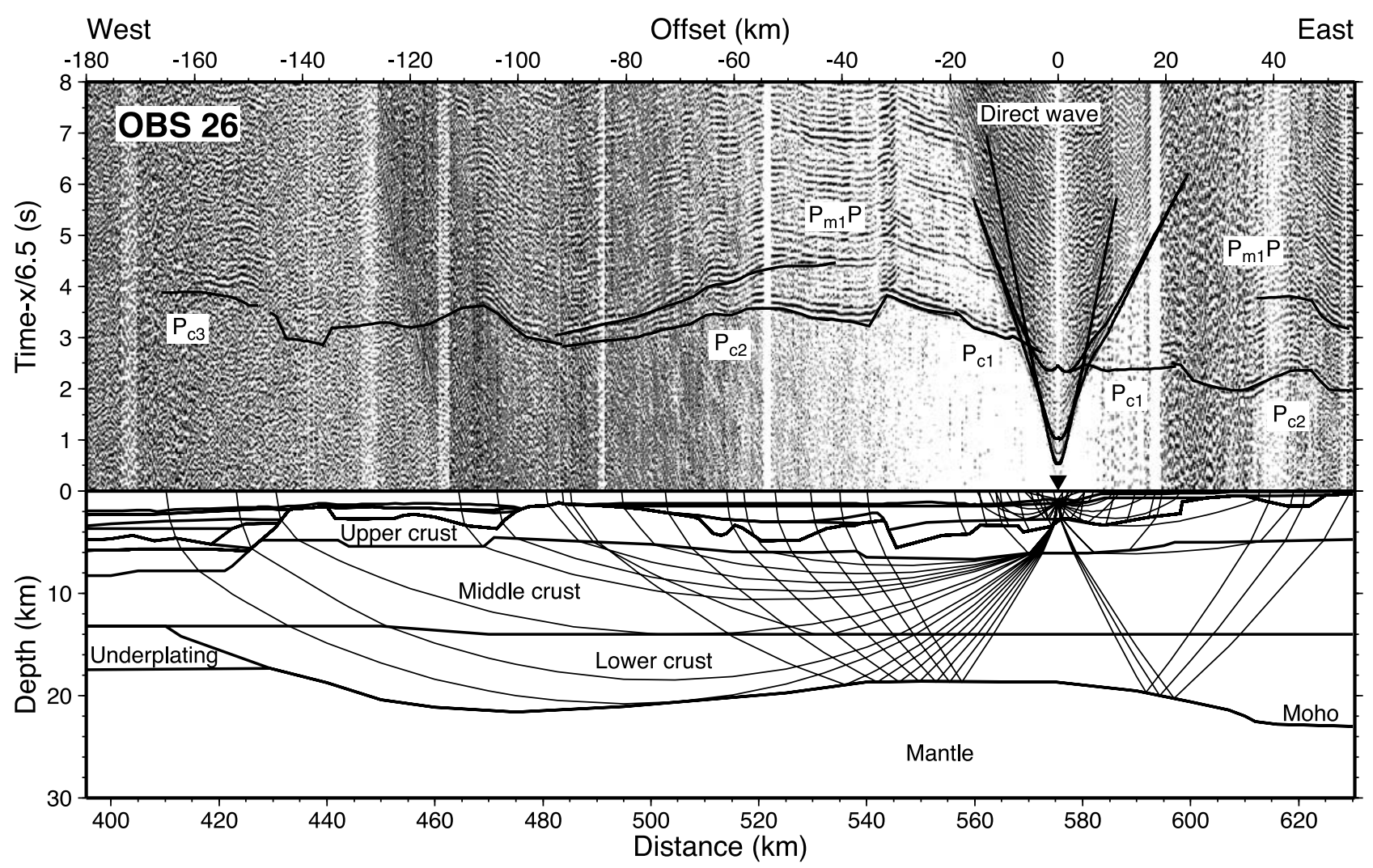

Figure 3. (top) Record section with computed travel times and (bottom) ray path diagram for the vertical geophone of OBS 26, located near the eastern end of the refraction line. Horizontal scale in the record section is shot-receiver distance (offset), and the vertical scale is the travel time using a reduction velocity of $6.5 \mathrm{~km} / \mathrm{s}$. A triangle indicates the receiver location. See text for description of phases and processing. The horizontal scale of the ray path diagram is distance along the velocity model (Figure 11).

Individual gun sizes ranged from $2.0 \mathrm{~L}$ to $16.4 \mathrm{~L}$. The array was fired every minute at an average ship's speed of 5.2 knots, which resulted in an average shot spacing of $161 \mathrm{~m}$. For navigation (OBS and shot locations) and shot timing, the Global Positioning System (GPS) was used. Water depths along the transect were obtained by converting measurements from the ship's echo sounder using a velocity-depth function obtained from the water column temperature readings of a heatflow measurement at the southern end of line 2.

[11] OBS data were converted to SEGY format, debiased, and corrected for OBS clock drift. Travel time picks of the direct wave were used to recalculate the position of the instrument at the seafloor, from which the shot-receiver ranges were calculated. A band-pass filter from 4 to $10 \mathrm{~Hz}$ was applied and on some stations a $6-\mathrm{Hz}$ notch filter was used along parts of the records to remove noise that was probably related to the generally strong tidal currents. Trace amplitudes in the record sections (Figures 3 through 7) are weighted by their distance to the OBS to increase amplitudes for large offsets.

\subsection{Methodology}

[12] The goal of the analysis of the refraction seismic data was to obtain a two-dimensional velocity model. In the ideal case, both receivers and shots are located along one single great circle arc. However, in order to connect the four wells, the line was split into five segments defined by the western and eastern endpoints of the line, and the four wells in between (Figure 2). These five segments are great circle arcs and define the baseline for the velocity model. After recalculation of the OBS positions on the seafloor, instrument positions were projected onto this baseline.

[13] The $P$ wave velocity model for the crust and uppermost mantle was developed using the program RAYINVR [Zelt and Smith, 1992; Zelt and Forsyth, 1994]. Initially, a forward model was developed from top to bottom (seafloor to manle) by fitting the observed travel times. The layer geometry down to basement was primarily defined by the coincident MCS record. In the vicinity of the four wells, sonic $\log$ data were used to adjust layer velocities and velocity gradients (Figure 8). In a second step, velocities within layers were optimized by using the inversion algorithm in RAYINVR. Upon changes in the velocity model, layer boundaries were adjusted to preserve the fit with the two-way travel times in the MCS data.

\subsection{Seismic Data}

[14] In general, the record sections have a high signal-tonoise ratio; on many stations refractions can be observed to offsets of up to $160 \mathrm{~km}$ (Figures 9 and 10). However, there are also many stations where the seismic energy cannot be correlated that far. This is often related to complexities in the velocity structure, such as low velocity zones and sharp 


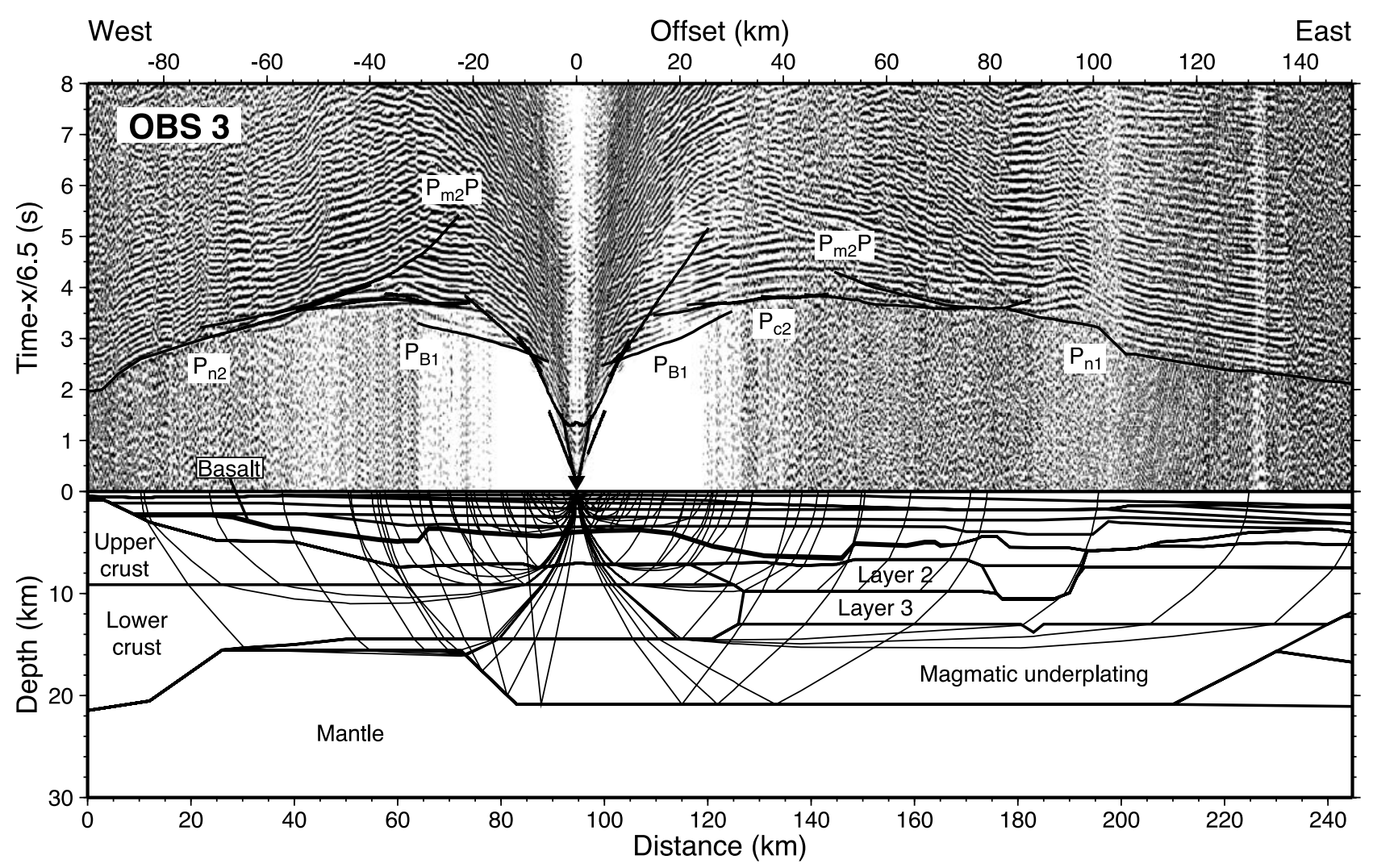

Figure 4. (top) Record section with computed travel times and (bottom) ray path diagram for the hydrophone of OBS 3, located near the western end of the refraction line. Horizontal scale in the record section is shot-receiver distance (offset), and the vertical scale is the travel time using a reduction velocity of $6.5 \mathrm{~km} / \mathrm{s}$. A triangle indicates the receiver location. See text for description of phases and processing. The horizontal scale of the ray path diagram is distance along the velocity model (Figure 11).

lateral velocity changes across structural boundaries. Many geophone components also had a tendency to pick up noise from tidal currents. However, in these cases the hydrophone component or a notch-filtered record section could be used instead.

[15] Observed seismic phases in the refraction/wide-angle reflection seismic data include refractions from three basaltic layers, two of them identified by drilling [Klose et al., 1982]. These refractions are labeled $P_{B 1}, P_{B 2}$, and $P_{B 3} . P_{B 2} P$ is the reflection from the base of the second basalt layer. Refractions in the continental crust were observed from three distinct layers and the corresponding phases are named $P_{c 1}, P_{c 2}$, and $P_{c 3}$, from top to bottom. $P_{c 1} P$ are reflections from the base of the upper crust and $P_{c 2} P$ is the midcrustal reflection. $P_{L 2}$ and $P_{L 3}$ are refractions within crustal layers where the velocities resemble those of oceanic layers 2 and 3 . Beneath the crust, a high velocity zone (HVZ) with velocities around $7.4 \mathrm{~km} / \mathrm{s}$ were observed. Refractions from this layer were labeled $P_{n 1}$, while refractions through the mantle were named $P_{n 2}$. Reflections from the base of the HVZ are marked as $P_{m 2} P$, while the name $P_{m 1} P$ is used for reflections from the base of the "normal" (i.e., $\leq 7.0 \mathrm{~km} / \mathrm{s}$ ) crust.

[16] A selection of record sections is shown in Figures 3 through 7 to illustrate some of the key features of the velocity structure along line 1. OBS 26 (Figure 3) is an example for the relatively simple structures encountered on the Greenland side of the transect. With increasing distance from the station refractions from deeper levels of the crust can be seen $\left(P_{c 1}, P_{c 2}\right.$, and $\left.P_{c 3}\right)$. The record also shows a curved shape of the first arrival times, which is related to a variable basement relief caused by faults and small basins. The Moho reflection $P_{m 1} P$ can be seen as a sharp and highamplitude phase for offsets $>40 \mathrm{~km}$.

[17] Record sections on the Baffin Island shelf at the western end of line 1 show a different signature than the stations off Greenland. On OBS 3 (Figure 4) a refraction $P_{B 1}$ from a basalt layer is observed with a phase velocity of $5.7 \mathrm{~km} / \mathrm{s}$ to the west and $5.2 \mathrm{~km} / \mathrm{s}$ to the east. Deeper refractions from the basement are delayed relative to the $P_{B 1}$, indicating the presence of a low-velocity zone beneath the basalts. To the east, a refraction $P_{n 1}$ that propagates through the HVZ (interpreted as magmatic underplating) is observed with a phase velocity of $7.3 \mathrm{~km} / \mathrm{s}$ up to an offset of $150 \mathrm{~km}$. To the west, a mantle refraction with a phase velocity of $7.9 \mathrm{~km} / \mathrm{s}$ for offsets up to $80 \mathrm{~km}$ and a velocity of $10 \mathrm{~km} / \mathrm{s}$ for offsets $>80 \mathrm{~km}$, indicates a shallowing of the basement at the western end of the line. Reflections $P_{m 2} P$ from the base of the HVZ can be seen at offsets $>25 \mathrm{~km}$.

[18] Probably one of the most important stations is OBS 10 (Figure 5), which shows pronounced differences between the observations to the west and to the east, indicating a lateral change of the velocity structure. In the west, there is a refraction $P_{B 2}$ through a basalt layer with a phase 


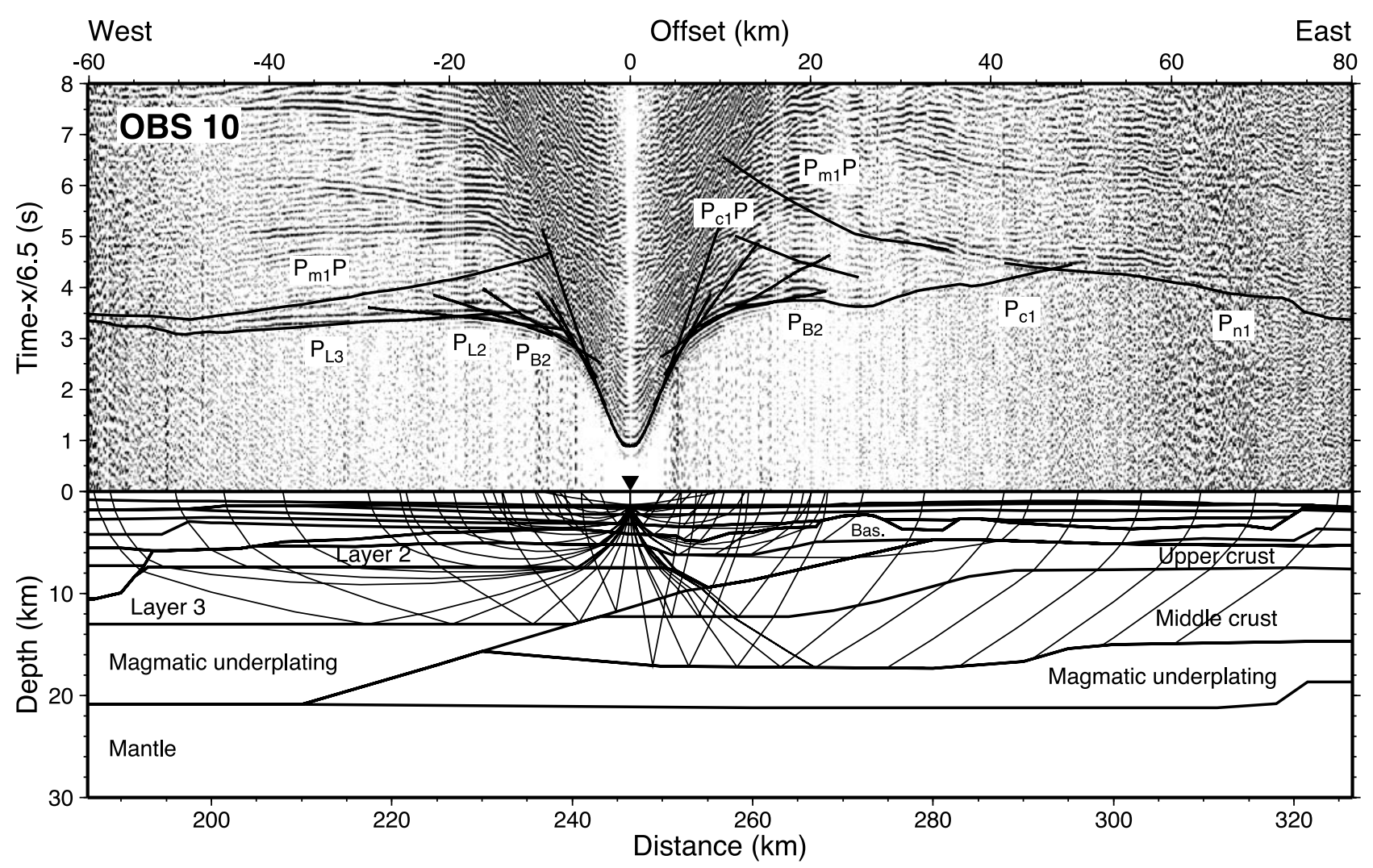

Figure 5. (top) Record section with computed travel times and (bottom) ray path diagram for the vertical geophone of OBS 10, located near the middle of the refraction line. Horizontal scale in the record section is shot-receiver distance (offset), and the vertical scale is the travel time using a reduction velocity of $6.5 \mathrm{~km} / \mathrm{s}$. A triangle indicates the receiver location. See text for description of phases and processing. The horizontal scale of the ray path diagram is distance along the velocity model (Figure 11). Note that some of the refractions were modeled as head waves to bypass raytracing problems at the dipping crustal boundary with sharp lateral velocity contrasts. Abbreviation Bas. is Basalts.

velocity of $4.7 \mathrm{~km} / \mathrm{s}$. At offsets of $12 \mathrm{~km}$, the $P_{L 2}$ phase becomes the first arrival with a phase velocity of $5.5 \mathrm{~km} / \mathrm{s}$, followed by the $P_{L 3}$ phase (velocity of $6.8 \mathrm{~km} / \mathrm{s}$ ) for offsets $>19 \mathrm{~km}$. Despite its rather low amplitude, a $P_{m 1} P$ reflection can be correlated between 12 and $45 \mathrm{~km}$ offset. $P_{L 2}$ and $P_{L 3}$ phases are absent to the east; instead there is a $P_{c 1}$ phase at offsets between 22 and $47 \mathrm{~km}$ with a phase velocity of $5.7 \mathrm{~km} / \mathrm{s}$. For larger offsets, the $P_{n 1}$ refraction in the HVZ becomes the first arrival (velocity of $7.5 \mathrm{~km} / \mathrm{s}$ ). Two reflections can be distinguished in the east, a crustal reflection $\left(P_{c 1} P\right)$ and a high-amplitude $P_{m 1} P$ reflection. In summary, OBS 10 marks the approximate transition between two different crustal types, with a layer to the west that displays typical velocities of oceanic layer 3 and a layer to the east with velocities more typical of continental crust.

[19] The next station to the east (OBS 11, Figure 6) also shows the lateral velocity variation. To the west, $P_{L 2}$ and $P_{L 3}$ refractions are observed with phase velocities of 6.1 and $7.0 \mathrm{~km} / \mathrm{s}$, respectively, while velocities to the east are $5.1 \mathrm{~km} / \mathrm{s}\left(P_{c 1}\right)$ and $6.3 \mathrm{~km} / \mathrm{s}\left(P_{c 2}\right)$. The lateral velocity variation causes low velocities zones because the boundary between the two crustal domains is westward dipping. Thus the lower velocity upper and middle crust in the east is located beneath the high velocity crust (layer 3 ) in the west. Ray tracing across this boundary was difficult, as can be seen by some of the raypaths (e.g., $P_{m 1} P$ and $P_{n 2}$ ).
[20] OBS 15 (Figure 7) is characterized by the absence of refractions from the crust $\left(P_{c 1}\right)$. This is related to the high velocities in the basalt sequence, which causes the underlying crust to become a low velocity zone. Phase velocities of the $P_{B 3}$ refraction within the basalt layer are $6.5 \mathrm{~km} / \mathrm{s}$ to the west and $5.4 \mathrm{~km} / \mathrm{s}$ to the east, which indicates a rock velocity of about $6.0 \mathrm{~km} / \mathrm{s}$ taking into account the dipping layer geometry. In contrast, crustal velocities in that area of the profile are only $5.4 \mathrm{~km} / \mathrm{s}$. Despite the absence of crustal refractions, both $P_{m 1} P$ and $P_{m 2} P$ reflections are observed, which define the top and bottom of the underplated layer. Travel time diagrams and raypaths for the remaining stations can be seen in Figures 9 and 10.

\section{Results}

\subsection{Velocity Model}

[21] The $P$ wave velocity model for NUGGET line 1 is shown in Figure 11. The sediments are divided into layers that follow the general trends of reflectivity in the coincident MCS data (TGS-NOPEC, line GreenCan 2001-12A). Sediment thickness is up to $6 \mathrm{~km}$ on the Canadian side of the profile (west) and up to $4.5 \mathrm{~km}$ off Greenland (east). The sediment thickness decreases to $<0.5 \mathrm{~km}$ above some of the basement highs between 430 and $630 \mathrm{~km}$. Velocities in the sedimentary basins range from $1.6 \mathrm{~km} / \mathrm{s}$ to $4.4 \mathrm{~km} / \mathrm{s}$ and 


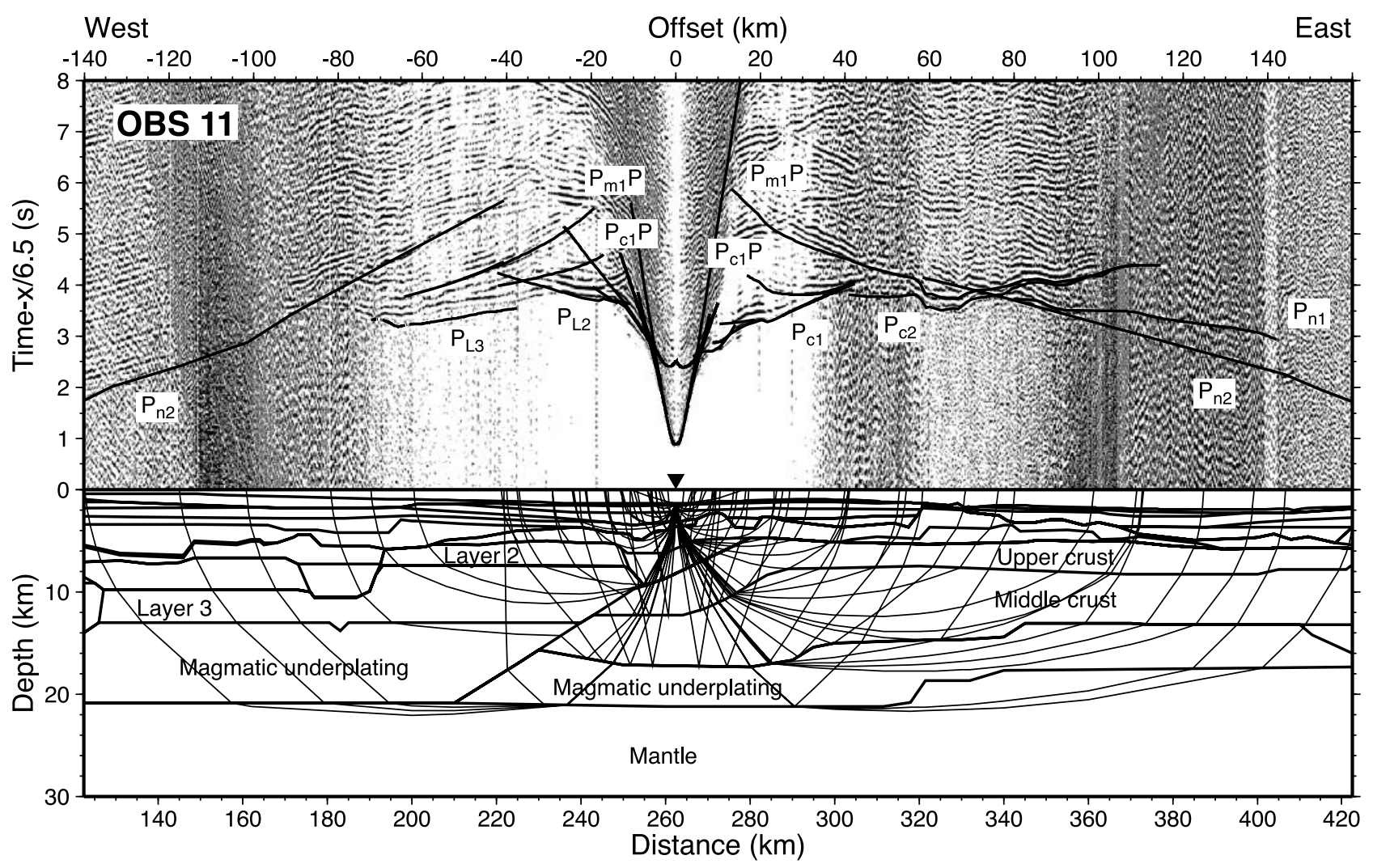

Figure 6. (top) Record section with computed travel times and (bottom) ray path diagram for the vertical geophone of OBS 11, located near the middle of the refraction line. Horizontal scale in the record section is shot-receiver distance (offset), and the vertical scale is the travel time using a reduction velocity of $6.5 \mathrm{~km} / \mathrm{s}$. A triangle indicates the receiver location. See text for description of phases and processing. The horizontal scale of the ray path diagram is distance along the velocity model (Figure 11).

generally increase with depth. However, between 40 and $130 \mathrm{~km}$ (roughly between OBS 1 and 4) a velocity inversion is observed beneath the second sediment layer (counted from the seafloor).

[22] West of $428 \mathrm{~km}$ (near OBS 19), volcanics are found underneath the sediments, based on the seismic velocities and the correlation with the wells. The top of the basalts is characterized by variable relief and velocities range from $4.3 \mathrm{~km} / \mathrm{s}$ in the centre of the line to $5.3 \mathrm{~km} / \mathrm{s}$ in the west. At the Hekja well, the $5.3 \mathrm{~km} / \mathrm{s}$ layer is an only $86-\mathrm{m}$-thick bed that consists of limestone, dolomite, and altered volcanics [Klose et al., 1982]. Below this $5.3 \mathrm{~km} / \mathrm{s}$ volcanic layer, velocities decrease (low-velocity zone) and are therefore not resolved by the seismic refraction experiment. In the model, a velocity of 4.3 to $5.2 \mathrm{~km} / \mathrm{s}$ was used in the low-velocity zone. At the Hekja well, this low-velocity zone consists of shale interbedded with basalt and, below a depth of $3800 \mathrm{~m}$, mostly of basalt [Klose et al., 1982]. Below $4200 \mathrm{~m}$ depth, sonic log velocities occasionally exceed those that were found at the top of the volcanic sequence $(5.3 \mathrm{~km} / \mathrm{s})$. Hence it is possible that the $P_{B 1}$ phase (Figure 4) not only sampled the 86-m-thick top of the sequence but also some deeper high-velocity portions of the basalts. However, these details cannot be resolved by the refraction seismic data. Basalts in the centre part of the line are drilled in the Gjoa well and are interbedded with shale and limestone [Klose et al., 1982].
To the east of the Gjoa well, a 1.5-km-thick layer with a velocity of $5.8 \mathrm{~km} / \mathrm{s}$ is observed, which is interpreted as basalt based on its velocity and the variable relief at its top. The high velocities in this layer create a low-velocity zone in the underlying crust. The overall thickness of the layers that contain volcanic rocks is up to $4 \mathrm{~km}$. However, the refraction seismic data do not allow a distinction between volcanics and sediments. Hence lower portions of the sequence below the maximum penetration depth of the wells may consist of sediments rather than volcanic rocks.

[23] The crust beneath the sediments and volcanics is divided into three distinct zones. Close to Baffin Island between 0 and $128 \mathrm{~km}$ (near OBS 4), the continental crust is divided in an upper layer $(5.8-6.1 \mathrm{~km} / \mathrm{s})$ and a lower layer $(6.4-6.6 \mathrm{~km} / \mathrm{s})$. The crust thins seaward and at its eastern termination the upper crust is $2 \mathrm{~km}$ thick and the lower crust is $5.5 \mathrm{~km}$ thick. The crust near Greenland between $410 \mathrm{~km}$ (OBS 18) and $630 \mathrm{~km}$ (east end of line) is divided into three layers with velocities of 5.4 to $5.6 \mathrm{~km} / \mathrm{s}$ in the upper crust, 6.4 to $6.6 \mathrm{~km} / \mathrm{s}$ in the middle crust, and 6.6 to $6.8 \mathrm{~km} / \mathrm{s}$ in the lower crust. The maximum Moho depth is $22 \mathrm{~km}$, while beneath the sedimentary basin around the Qulleq well it is $19 \mathrm{~km}$. West of $410 \mathrm{~km}$ (near OBS 18), the crust thins abruptly and there is no seismic evidence that the lower crust continues westward. The upper crust between 250 and $425 \mathrm{~km}$ is about $2.5 \mathrm{~km}$ thick with velocities of 5.4 to 


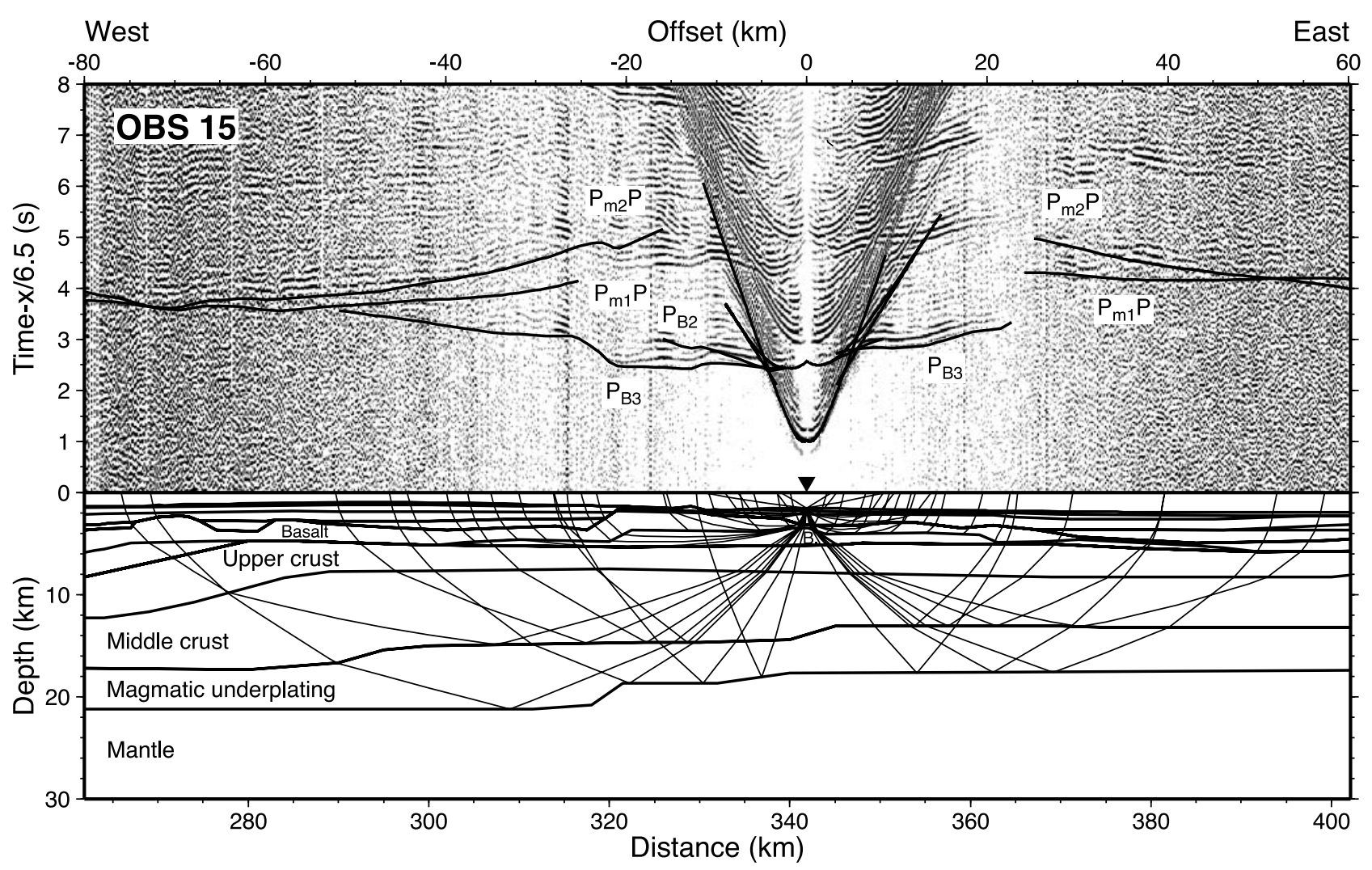

Figure 7. (top) Record section with computed travel times and (bottom) ray path diagram for the hydrophone of OBS 15, located at the middle of the refraction line. Horizontal scale in the record section is shot-receiver distance (offset), and the vertical scale is the travel time using a reduction velocity of $6.5 \mathrm{~km} / \mathrm{s}$. A triangle indicates the receiver location. See text for description of phases and processing. The horizontal scale of the ray path diagram is distance along the velocity model (Figure 11). Abbreviation B. is Basalt.

$5.6 \mathrm{~km} / \mathrm{s}$. The thickness of the middle crust varies between 5 and $8 \mathrm{~km}$ and velocities range from 6.4 to $6.6 \mathrm{~km} / \mathrm{s}$. Upper and midcrustal velocities are therefore similar to the thicker crust landward towards Greenland.

[24] The third crustal zone extends from about 115 to $255 \mathrm{~km}$ (between OBS 4 and 10) and displays a very different velocity structure from the neighboring Baffin Island and Greenland continental crust. The upper layer varies in thickness between 2 and $3 \mathrm{~km}$, and lateral velocity variations are observed with a total velocity range from 5.4 to $6.2 \mathrm{~km} / \mathrm{s}$. The underlying layer is $3 \mathrm{~km}$ thick in the west and $5 \mathrm{~km}$ in the east, with velocities ranging from 6.7 to $7.0 \mathrm{~km} / \mathrm{s}$. On the basis of these characteristics, this zone is interpreted as oceanic crust (oceanic layers 2 and 3).

[25] Beneath the 6 to $7.5-\mathrm{km}$-thick oceanic crust, a high velocity zone $(7.4 \mathrm{~km} / \mathrm{s})$ is observed that extends beneath the thinned portions of the adjacent continental crust. This zone is interpreted as magmatic underplating, with a maximum thickness of $8 \mathrm{~km}$ beneath the oceanic crust. To the east, the underplating extends in a $\sim 4-\mathrm{km}$-thick layer up to $430 \mathrm{~km}$ (near OBS 19), where the Greenland crust starts to thicken substantially. To the west, the underplating continues under the Baffin Island crust as a 6-km-thick layer but at $80 \mathrm{~km}$ it seems to thin. However, the resolution in this area is low. Mantle velocities are best constrained under the central part of the line and are modeled with a velocity of $7.9 \mathrm{~km} / \mathrm{s}$.

\subsection{Model Resolution and Uncertainty}

[26] The formal error analysis for individual phases is summarized in Table 1. The normalized $\chi^{2}$ in Table 1 is based on assigned pick uncertainties of 30-250 ms depending on the quality of each individual travel time pick. Pick uncertainties are graphically indicated in Figures 9 and 10. The model is generally well constrained with a total RMS misfit of 96 ms between calculated and picked travel times. The normalized $\chi^{2}$ of 1.03 is close to the optimum value of 1.0 when travel times are fitted within the given pick uncertainty.

[27] Figure 11 shows the values of the diagonal of the resolution matrix for the velocity nodes of the model. The lateral spacing of velocity nodes was generally $<25 \mathrm{~km}$ in the sediments, basalts and upper crust; farther below the spacing increases to a maximum of $50 \mathrm{~km}$ in the mantle. Ideally, values of the resolution matrix are 1 but values $>0.5$ indicate reasonably well resolved model parameters [Lutter and Nowack, 1990]. Resolution is excellent within the thick crust on the Greenland side of the transect but also the remainder of the crust and the underplated layer have resolution values of $>0.5$ in most areas. The major exception is the upper crust off Baffin Island, where short $P_{c 1}$ 
Table 1. Number of Observations, $n$, RMS Misfit Between Calculated and Picked Travel Times, $t_{r m s}$, and Normalized $\chi^{2}$ for Individual Phases

\begin{tabular}{lrcc}
\hline \multicolumn{1}{c}{ Phase } & \multicolumn{1}{c}{$n$} & $t_{r m s}, \mathrm{~ms}$ & $\chi^{2}$ \\
\hline Direct wave & 2753 & 31 & 0.366 \\
$P_{S}$ and $P_{S} P$ (all sediments) & 3433 & 71 & 0.892 \\
$P_{B 1}$ & 467 & 72 & 1.165 \\
$P_{B 2}$ & 581 & 65 & 1.049 \\
$P_{B 2} P$ & 15 & 33 & 0.181 \\
$P_{B 3}$ & 869 & 72 & 0.619 \\
$P_{c 1}$ & 1827 & 92 & 1.654 \\
$P_{c 1} P$ & 755 & 73 & 0.723 \\
$P_{c 2}$ & 5614 & 91 & 0.777 \\
$P_{c 2} P$ & 173 & 75 & 0.557 \\
$P_{c 3}$ & 881 & 118 & 0.688 \\
$P_{L 2}$ & 1028 & 112 & 0.564 \\
$P_{L 2} P$ & 34 & 181 & 9.423 \\
$P_{L 3}$ & 1451 & 92 & 1.207 \\
$P_{m 1} P$ & 5188 & 118 & 1.294 \\
$P_{n 1}$ & 2042 & 100 & 1.240 \\
$P_{m 2} P$ & 1951 & 96 & 0.805 \\
$P_{n 2}$ & 995 & 176 & 3.099 \\
All phases & 30,057 & 96 & 1.029 \\
& & &
\end{tabular}

branches (Figure 9) were observed with little ray overlap, resulting in a formal low resolution. However, the few $P_{c 1}$ observations are fit by the velocity model. The lower crust in this area has an acceptable resolution east of $70 \mathrm{~km}$. West of $70 \mathrm{~km}$, observations are not reversed and result in a low resolution.

[28] Low-velocity zones in the model have a low resolution, as no refractions are observed. This includes the upper crust around $350 \mathrm{~km}$ and the interbedded basalt and sediment layer between 10 and $170 \mathrm{~km}$. In general, the resolution in the sediments is often reduced due to the lack of good reverse ray coverage (station spacing is too wide compared to the length of the observed refraction branches). However, this shortcoming is compensated by the reflection seismic data, which define the layer boundaries very well and limit how much the velocity can be varied.

[29] The zone with the largest uncertainty is the underplated layer west of $80 \mathrm{~km}$ (Figure 11), where the model shows a 1-km-thick continuation of the interpreted magmatic underplating. The observed reflection points between 40 and $70 \mathrm{~km}$ (at a depth of $15.5 \mathrm{~km}$ ) could as well come from the base of the lower crust $\left(P_{m 1} P\right)$, as no $P_{n 1}$ phases were observed in that area. In this scenario, the underplated material would pinch out at $70 \mathrm{~km}$. In the course of the modeling, the underplated material was also considered as a thick layer until it reaches the thick continental crust at the western limit of the transect. However, a $P_{n 2}$ phase from OBS 3 (Figure 4) could not be modeled with velocities observed in the underplated layer $(7.4 \mathrm{~km} / \mathrm{s})$, but required velocities close to $8.0 \mathrm{~km} / \mathrm{s}$ at a depth of $16 \mathrm{~km}$. In addition, the high-amplitude reflections from the 21-km-deep base of the underplated layer (observed at OBS 2 through 4) do not continue west of $70 \mathrm{~km}$.

[30] To determine the uncertainty of the velocity and boundary nodes, single nodes of the model were perturbed and the travel times were checked for their sensitivity to these variations. The uncertainty of crustal velocities was found in general to be $\pm 0.1 \mathrm{~km} / \mathrm{s}$ but slightly higher at the western limit of the profile $( \pm 0.15 \mathrm{~km} / \mathrm{s})$. The velocity uncertainty within the sediments and basalts varies between
0.1 and $0.2 \mathrm{~km} / \mathrm{s}$. No absolute error can be given for the areas of the model that are low-velocity zones. Layer boundaries can be varied at most by $1 \mathrm{~km}$ in depth. However, there are portions of the top and base of the magmatic underplating and of the Moho that are not sampled by wide-angle reflections (as indicated in Figure 11) and those segments are not fully constrained.

[31] The velocity model (Figure 11) contains details that are difficult to resolve by refraction seismic data alone, like the small-scale structure of the sediments and the basalt layers, the positions where layers pinch out and sharp lateral velocity variations between different crustal types. This raises the question if unnecessary structure has been introduced to the model. The use of the coincident MCS data for modeling purposes was done in a very conservative way. Layers and lateral velocity variations were only introduced to the model when corresponding phases were recognized in the refraction seismic data. The coincident reflection seismic data then were consulted to check for correlations between the velocity model and the reflectivity pattern. Details that were taken from the MCS data were removed if they did not improve the overall fit of the velocity model.

\subsection{Gravity Modeling}

[32] Two-dimensional gravity modeling (algorithm of Talwani et al. [1959]) was performed along line 1 to verify how consistent the velocity model is with the gravity data. The data used in the model (Figure 12) were extracted from the gravity map of Oakey et al. [2001b]. The initial density model (model A) was obtained from conversion of $P$ wave velocities to density using the curve shown in the work of Ludwig et al. [1970] that is approximated by

$$
\rho=-0.00283 v^{4}+0.0704 v^{3}-0.598 v^{2}+2.23 v-0.7
$$

where $\rho$ is the density in $\mathrm{g} / \mathrm{cm}^{3}$ and $v$ is the $P$ wave velocity in $\mathrm{km} / \mathrm{s}$. The only modification to this density model was applied to the mantle, where a lateral variation was introduced to match the long-wavelength component of the gravity anomaly. East of $440 \mathrm{~km}$ beneath the thick continental crust of Greenland, a mantle density of $3.33 \mathrm{~g} / \mathrm{cm}^{3}$ was used, while the remainder of the mantle was modeled with a density of $3.30 \mathrm{~g} / \mathrm{cm}^{3}$.

[33] In general, the calculated and observed gravity (model A, Figure 12) match very well and some of the misfit is probably related to deviations from the assumed two-dimensionality of the model. As the potential field maps (Figure 13) show, there are many anomalies that cut line 1 at an oblique angle. Figure 12 also shows that the faulted basement blocks on the Greenland shelf between 420 and $630 \mathrm{~km}$ create short-wavelength signals in the calculated anomaly, while the shape of the observed gravity is smoother. This indicates that the basement blocks are not completely two-dimensional.

[34] One misfit that was investigated in some detail is west of $160 \mathrm{~km}$ on the Baffin Island shelf (Figure 12). Here the deviation between observed and calculated gravity becomes progressively larger landward with a misfit of up to $30 \mathrm{mgal}$. In model $\mathrm{A}$, the density model extends horizontally to the west of $0 \mathrm{~km}$. However, at a continental margin changes in the crustal thickness can be expected and therefore we have extended the model by $50 \mathrm{~km}$ to 


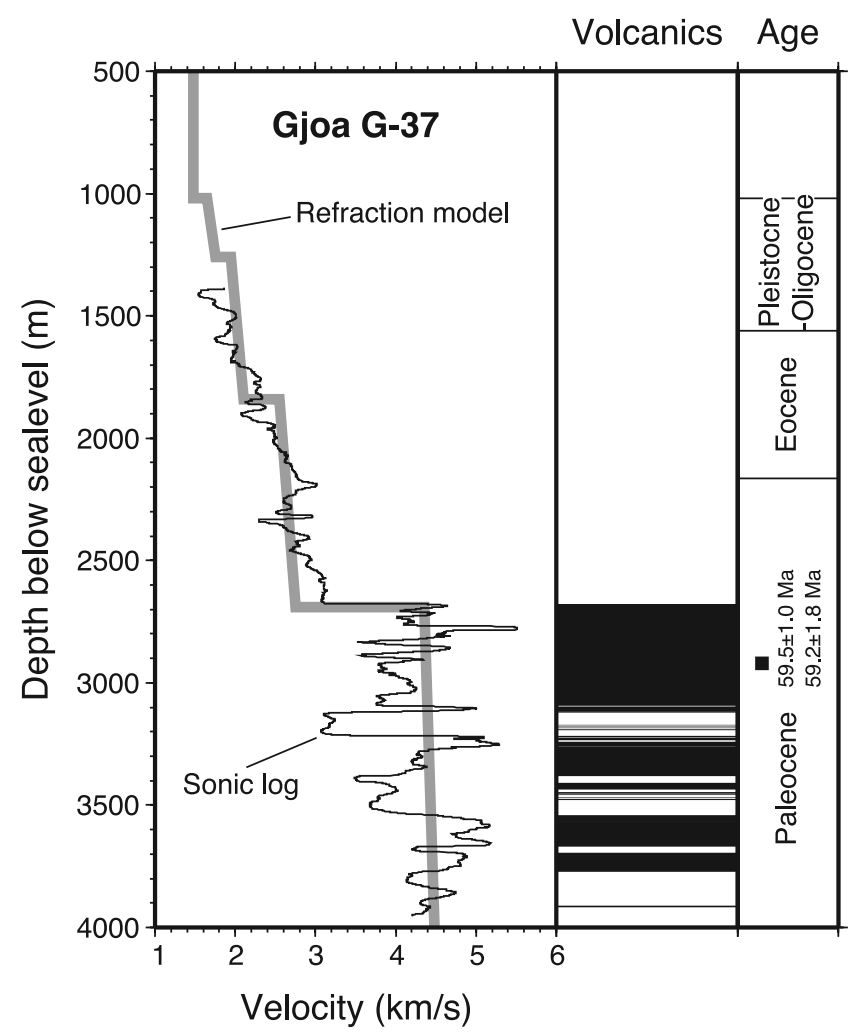

Figure 8. (left) Velocity-depth profiles at the location of the Gjoa G-37 well. Gray line extracted from the velocity model shown in Figure 11; solid line represents the sonic $\log$ velocity (BASIN database, Geological Survey of Canada, Dartmouth, Nova Scotia, Canada) using a median filter with a width of $20 \mathrm{~m}$. (middle) Black areas show the segments of the well in which volcanic rocks where drilled (BASIN database). (right) Age of the sediments and rocks at the well [Klose et al., 1982]; the square indicates the depth of the basalts that were dated by Williamson et al. [2001].

introduce a gradual thickening of the crust from 21 to $28 \mathrm{~km}$ (model B). This resulted in a better fit at the western end of the line but the calculated gravity between 30 and $160 \mathrm{~km}$ is still about 20 mgal higher than the observed gravity. In another alternative (model C), we thickened the highvelocity zone (interpreted as underplating) in the west between 12 and $80 \mathrm{~km}$. The effect on the calculated gravity is that model $\mathrm{C}$ lies closer to the observed gravity than model B. However, it should be noted that the general curvature in the observed gravity, in particular the dip at $100 \mathrm{~km}$ fits better in model B. Despite the low seismic resolution, the few $P_{n}$ and $P_{m} P$ observations are better explained with model $\mathrm{B}$ than with model $\mathrm{C}$. Therefore it appears more likely that the deviation between model B and the observed gravity is related to another effect that is not properly incorporated into the model. One possibility is that the crust not only thickens to the west of line 1 but also to the NW towards SE Baffin Island as inferred from the gravity map (Figure 13) by using the 0-mgal-contour around Baffin Island as a proxy for thick continental crust. This effect cannot be incorporated into a two-dimensional model. However, a thickening of the crust to the NW would decrease the calculated gravity and reduce the misfit to the observed gravity. The gravity map (Figure 13) also shows that this northwestward crustal thickening would mostly affect the western part of the line up to OBS 5 (corresponding to $150 \mathrm{~km}$ model distance), exactly where the gravity misfit is observed.

\section{Discussion}

[35] The velocity model (Figure 11) across Davis Strait shows four distinct features: continental crust along most of line 1, a sub-region with oceanic crust, Paleogene basalts overlying the crust, and an underplated layer at the base of the crust. This gross division was introduced in section 4.1 and will now be discussed in more detail. In particular we want to focus on the interaction between the transform margin in Davis Strait and the proposed Iceland plume beneath Greenland [Storey et al., 1998; Larsen and Saunders, 1998].

\subsection{Paleogene Basalts (0 to $428 \mathrm{~km}$ )}

[36] Paleogene basalts [Williamson et al., 2001] with velocities between 4.2 and $5.8 \mathrm{~km} / \mathrm{s}$ extend from the western part of line 1 entirely across Davis Strait, up to a prominent fault off Greenland at $428 \mathrm{~km}$ model distance (Figure 11). No seismic evidence for basalts was found along the eastern part of the line. Three wells (Hekja O-71, Ralegh N-18, and Gjoa G-37) were drilled into the basalts and support the interpretation of the velocity model. However, the drilling results also show that the basalts are interbedded with sediments, at the Hekja well with chalky clays and at the Gjoa well (Figure 8) with Paleocene marine shales and limestone [Klose et al., 1982]. The resolution of the refraction seismic experiment is not sufficient to distinguish any of the interbedded sediments because the velocities of the sediments overlap with those of the basalts. In addition, the uppermost portion ( $86 \mathrm{~m}$ at the Hekja well) of the basalt/sediment unit between 10 and $165 \mathrm{~km}$ is a high velocity zone $(5.3 \mathrm{~km} / \mathrm{s})$, which prevents a detailed velocity analysis in the underlying low-velocity zone. Below the drilling penetration little can be said about the composition of the combined basalt and sediment unit. It is possible that basalts are absent in the lowermost section of this unit. The reflection seismic data show two distinct reflection patterns at the Ralegh well that drilled $20 \mathrm{~m}$ into the topmost volcanics (Figures 14 and 15). The upper half (3.0-3.6 s two-way travel time) of the underlying basalt/sediment unit is characterized by mostly parallel and disrupted reflectors that may be mainly composed of individual lava flows. Below, the reflectivity becomes more irregular which could argue for a different composition, possibly sediments that

Figure 9. Comparison of observed and calculated travel times for OBS 1-16, shown together with the corresponding ray paths. Observed data are indicated by vertical bars, with heights representing pick uncertainty; calculated data are indicated by solid lines. Triangles mark the receiver locations. Horizontal scale is the model position; a reduction velocity of $6.5 \mathrm{~km} / \mathrm{s}$ has been applied for the travel times. 

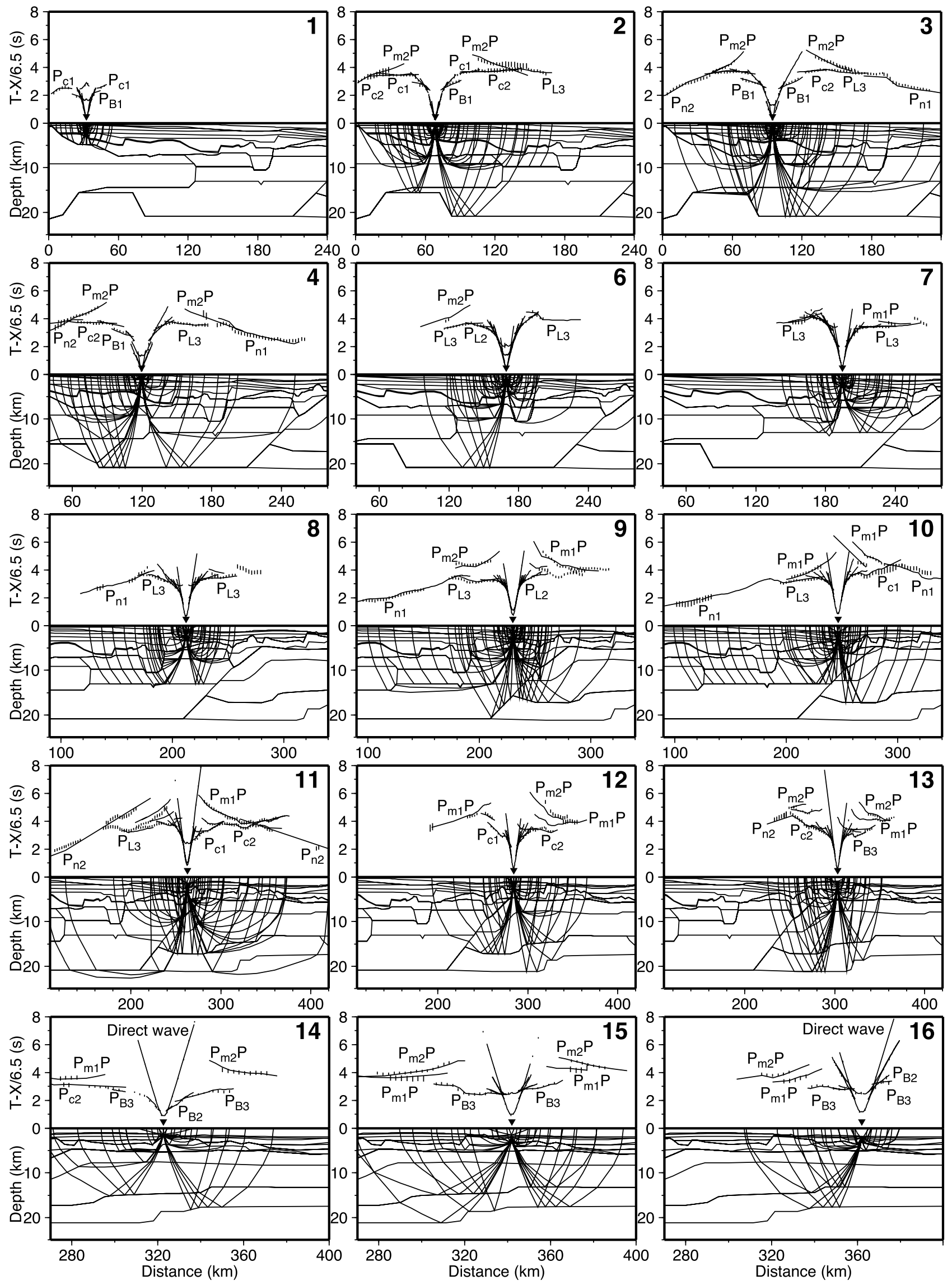

Figure 9 

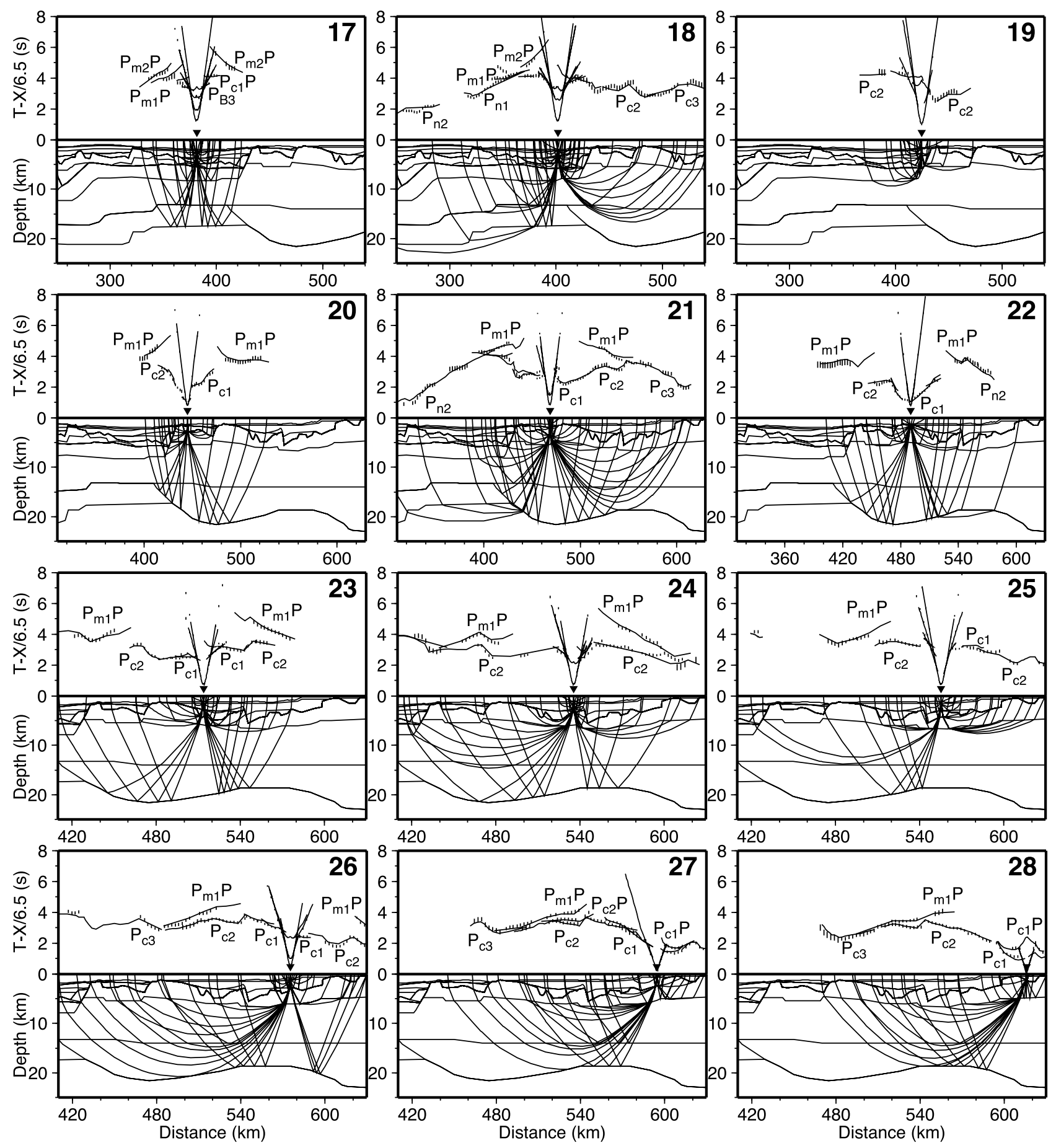

Figure 10. Same as Figure 9 for OBS 17-28.

predate the Paleogene volcanism. Both refractions and MCS data define the geometry of the underlying basement and suggest that the thickness of the combined basalt/sediment unit is less than $4 \mathrm{~km}$.

\subsection{Oceanic Crust (115 to $255 \mathrm{~km}$ )}

[37] While most of the crust along line 1 is of continental character, there is a $140-\mathrm{km}$-wide zone (between 115 and $255 \mathrm{~km}$ model distance, Figure 11) with a two-layered velocity structure that resembles oceanic layers 2 and 3 . Typical oceanic crust has a $2-\mathrm{km}$ thick layer 2 with velocities between 2.5 and $6.6 \mathrm{~km} / \mathrm{s}$ and a $5-\mathrm{km}$ thick layer 3 with velocities between 6.6 and $7.6 \mathrm{~km} / \mathrm{s}$ [White et al., 1992]. The crust between 115 and $255 \mathrm{~km}$ on line 1 (Figure 11) fits well into this range and this is why we use the generic term "oceanic crust" for this part of the line. However, the geological setting in this zone is unlikely to be that of a sea-floor spreading system but more complicated because here the former Labrador Sea mid-ocean ridge terminated against a continent and a transform fault. On the basis of the velocity, potential field and reflection seismic data, we subdivide the oceanic crust into two zones 

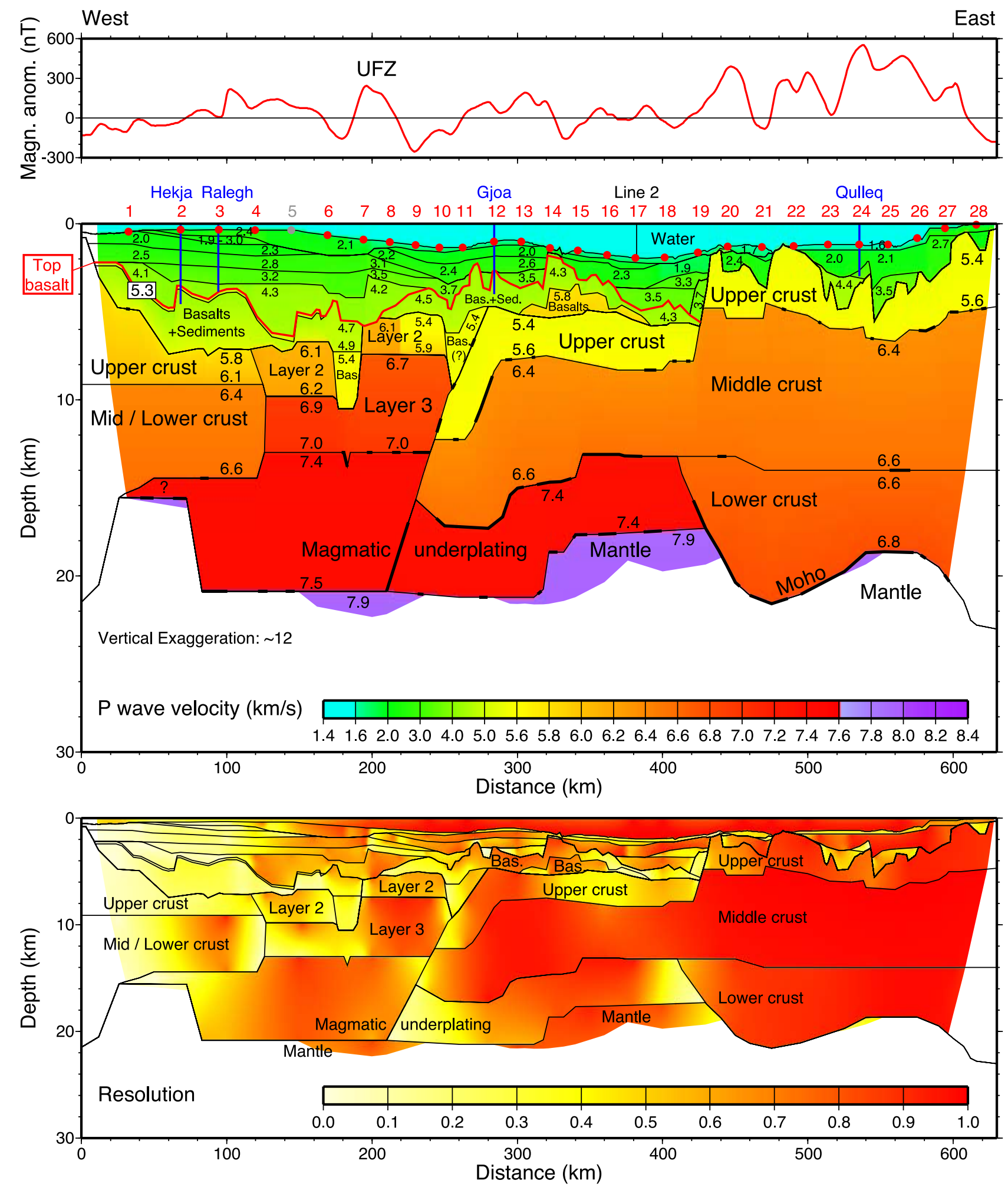

Figure 11. (middle) $P$ wave velocity model along line 1 . Numbers indicate velocity, in $\mathrm{km} / \mathrm{s}$. The outer perimeter of the model with no ray coverage is omitted. Layer boundaries constrained by wide-angle reflections are drawn with bold solid lines. Red circles mark the location of the OBS used for the modeling; the gray circle shows the location of OBS 5 that was not recovered. Vertical blue lines show the location of deep exploration wells and their penetration. Position of intersection with line 2 is marked by a solid line. The top of the Paleogene basalts is marked by a red line. (bottom) Diagonal values of the resolution matrix of the $P$ wave velocity model. (top) Magnetic anomalies along the seismic line taken from Oakey et al. [2001c]. Abbreviations are Bas., Basalts; Sed., Sediments; UFZ, Ungava fault zone. 


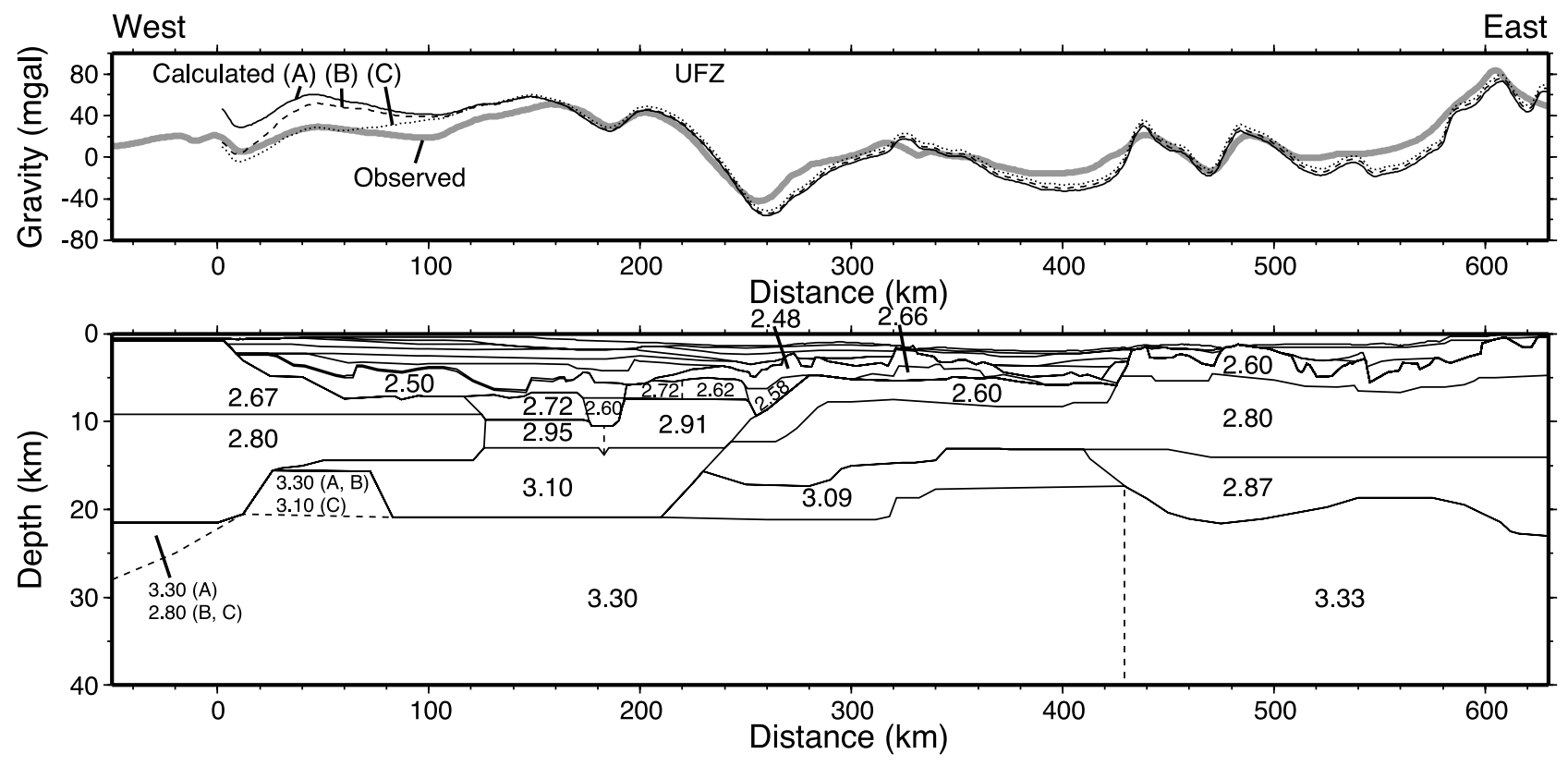

Figure 12. Two-dimensional gravity modeling for line 1 . The $P$ wave velocity model (Figure 11) was converted to density using the velocity-density relationship of Ludwig et al. [1970] with slight modification to the densities in the mantle (model A). In model B, the Moho geometry is changed to the west of the velocity model between -50 and $0 \mathrm{~km}$ (see text for discussion). In model $\mathrm{C}$ also the thickness of the underplated layer is increased in the west. (bottom) Densities in the model, given in $\mathrm{g} / \mathrm{cm}^{3}$. (top) Observed (gray line) and calculated gravity (model A: solid line; model B: dashed line; model C: dotted line). Abbreviation UFZ is Ungava fault zone.

that are separated by a graben structure between OBS 6 and 7 at $185 \mathrm{~km}$ model distance (Figure 11). Within the graben, velocities in the upper crust $(5.4 \mathrm{~km} / \mathrm{s})$ are different than those found to the west and east $(6.1 \mathrm{~km} / \mathrm{s})$. This division can also be seen in the gravity data (Figures 12 and 13), where the oceanic crust is characterized by a positive gravity anomaly, which is slightly reduced (by 14 mgal) within the graben structure. This reduction of the free-air gravity cannot just be an effect of the increasing water depth since the anomaly is also visible in the Bouguer gravity (G. Oakey, personal communication, 2005). The oceanic crust in the west is adjacent to a volcanic-style margin, while the oceanic crust in the east is related to the transform margin and the Ungava fault zone (UFZ). Here the oceanic crust was most likely created by upwelling of magma in areas with transtensional movements along the UFZ. The volcanics sampled in the wells [Williamson et al., 2001] and the volcanic margin observed along West Greenland [Storey et al., 1998] postdate the onset of sea-floor spreading in this region [Chalmers and Laursen, 1995].

\subsection{Volcanic-Style Continental Margin (0 to $180 \mathrm{~km})$}

[38] Within the oceanic crust to the west of the graben structure (between 115 and $180 \mathrm{~km}$, Figure 11) seaward dipping reflectors (SDRs) are observed on the coincident TGS-NOPEC MCS line 2001-12A (Figures 14 and 15). Such reflectors are characteristic for volcanic-style continental margins. The SDRs originate in the basalt and sediment unit where the reflectors are horizontal landward of $105 \mathrm{~km}$ (Figure 15). Seaward, the dip changes and the reflectors merge into the oceanic crust. In the area of the SDRs, the velocity model (Figure 11) shows a first order velocity discontinuity between the basalt unit and oceanic layer 2 (between 116 and $140 \mathrm{~km}$ ). The coincident MCS record section (Figure 15) does not show any reflectivity associated with this layer boundary, which suggest a gradational velocity transition. However, the few available wide-angle data from OBS 4 and 6 (OBS 5 was lost) and the additional complications associated with the velocity inversion within the basalts did not allow us to resolve the details of the velocity structure across this boundary.

[39] Comparisons to other volcanic margins show that the velocity structure along this margin segment differs from "typical" volcanic margins. Wide-angle seismic profiles across the volcanic margins at the U.S. East Coast [Holbrook et al., 1994a; 1994b] and East Greenland [Holbrook et al., 2001; Hopper et al., 2003] show that the rifted continental crust is still fairly thick in the transitional zone where the igneous crust (composed of basalts, mafic intrusions, and underplating) is first observed. The Moho depth at the breakup point varies between 20 and $35 \mathrm{~km}$ in these examples. In contrast, the base of the continental crust on line 1 is at $15 \mathrm{~km}$ and the crustal thickness is already reduced to $7 \mathrm{~km}$. We interpret these deviations from a typical volcanic margin as a result of an essentially nonvolcanic initial rifting phase that was later overprinted by volcanism associated with the Greenland-Iceland plume.

[40] Basin formation off Labrador was initiated by Barremian to mid-Coniacian time when the cratonic basement underwent extension followed by thermal subsidence [Balkwill, 1987]. The start of sea-floor spreading in Labrador Sea is controversial, ranging from magnetic chron 33 (79.7-74.5 Ma) [Roest and Srivastava, 1989] to chron 27 

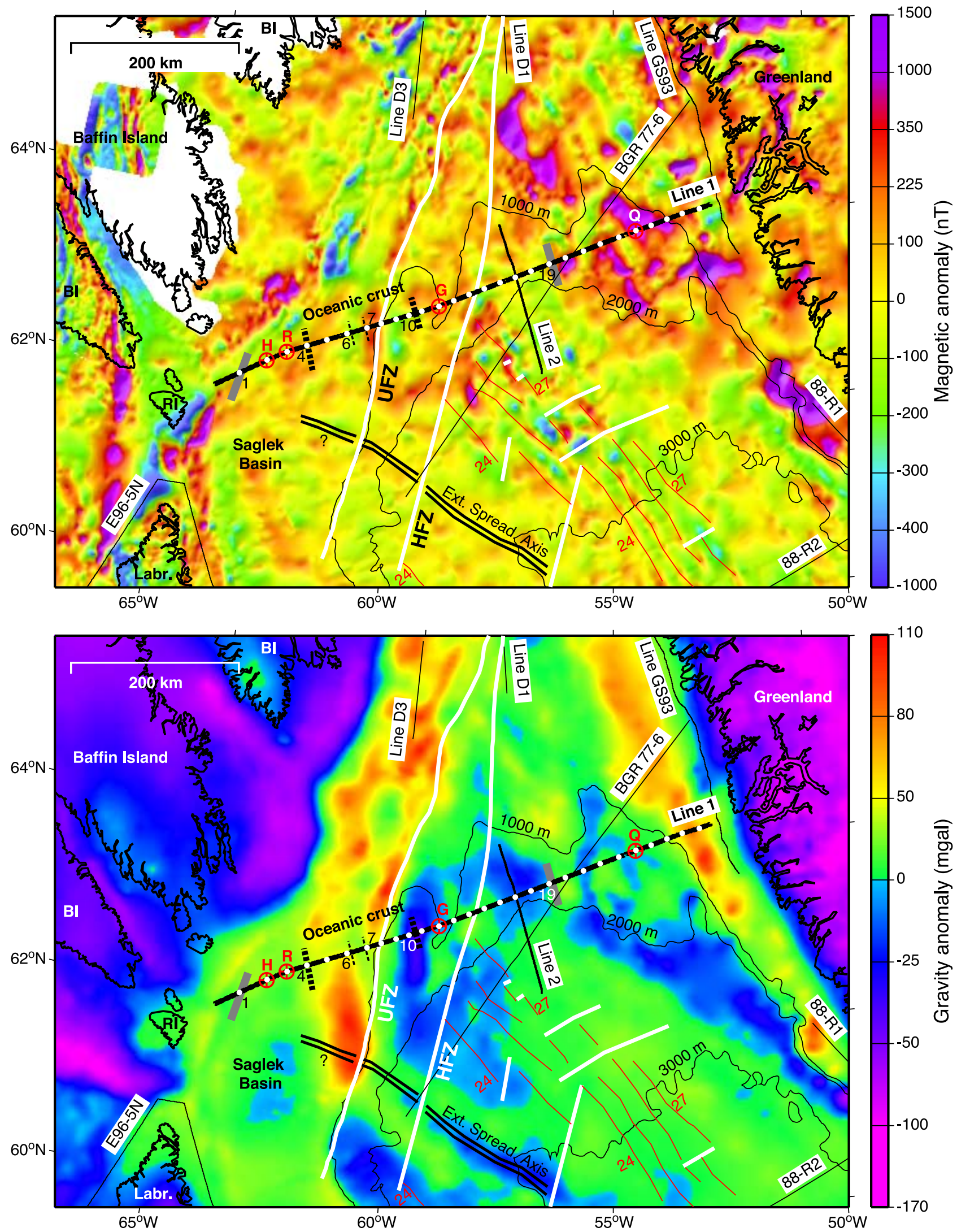

Figure 13 


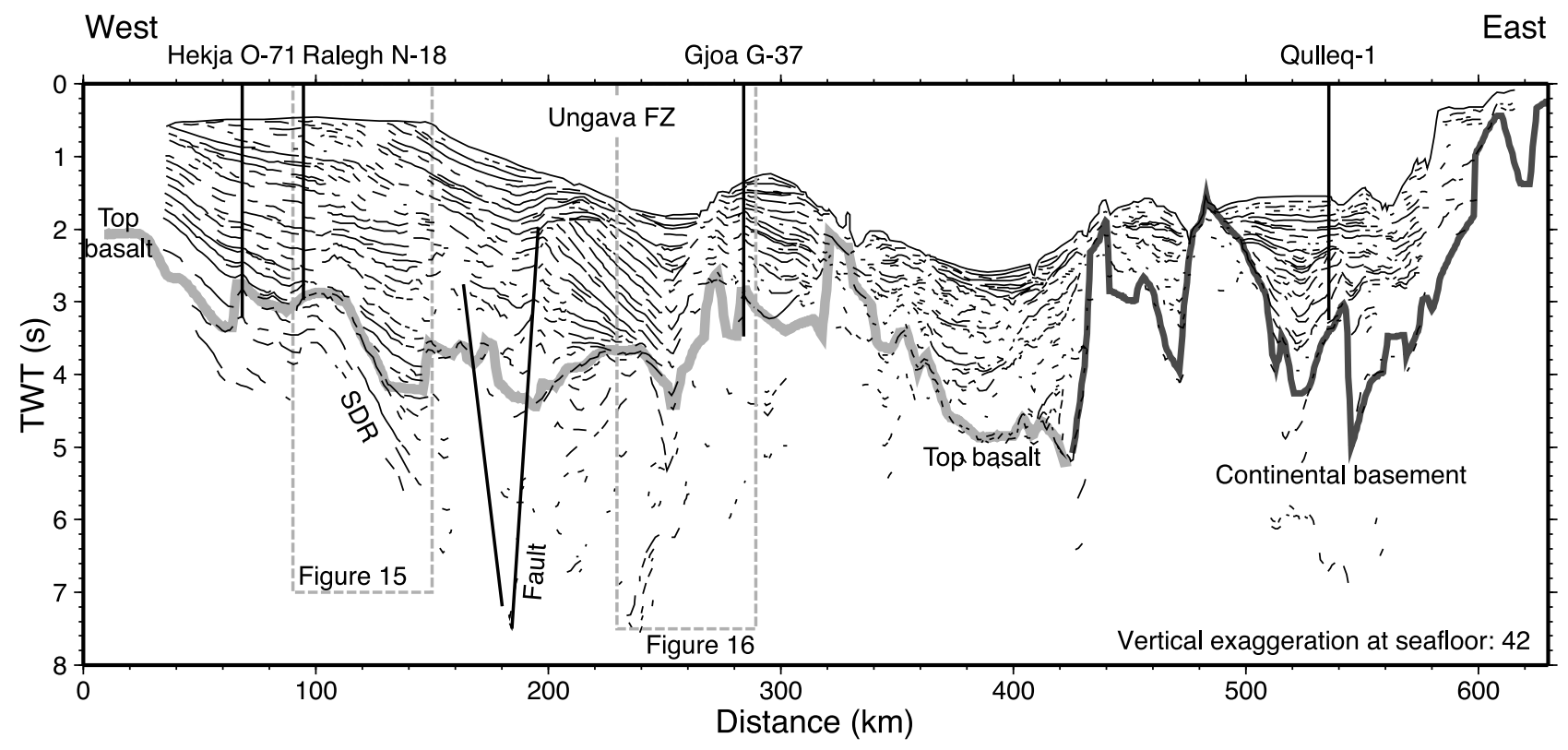

Figure 14. Line drawing of migrated multichannel seismic line GreenCan 2001-12A collected by TGSNOPEC. This line is coincident with line 1. Vertical scale is two-way travel time; horizontal scale is the distance along the velocity model of NUGGET line 1 (Figure 11). Vertical solid lines show the location of deep exploration wells and their penetration. Dashed gray frames refer to the record sections shown in Figures 15 and 16. A bold light gray line shows the top of the Paleogene basalts and a bold dark gray line indicates the top of the continental basement as derived from the velocity model. Abbreviations are FZ, fault zone; SDR, seaward dipping reflectors.

(61.3-60.9 Ma) [Chalmers and Laursen, 1995]. The onset of spreading probably gets younger to the north [Roest and Srivastava, 1989]. All the observed volcanism in the Davis Strait region lies in the time window from 63 to $54 \mathrm{Ma}$ [Storey et al., 1998; Williamson et al., 2001], which postdates the rifting phase and probably the onset of sea-floor spreading. Hence there is good reason to assume that the extension and thinning of the continental crust on line 1 happened in a nonvolcanic style. This is also in agreement with the general rifting style farther to the south in Labrador Sea, where zones of serpentinized mantle were found in the continent-ocean transition zone off Labrador [Chian et al., 1995b] and SW Greenland [Chian and Louden, 1994]. Serpentinized mantle is common along nonvolcanic margins but has never been observed along volcanic margins.

[41] A refraction seismic profile across northern Labrador (line E96-5, for location see Figure 1) some $330 \mathrm{~km}$ to the south of line 1 shows no evidence for volcanism as no basalt layer or underplating was observed [Funck and Louden, 1999]. It should also be noted that the necking profile of the continental crust on line E96-5 very much resembles line 1. The Moho depth on line E96-5 shallows from 38 to $17 \mathrm{~km}$ over a lateral distance of $40 \mathrm{~km}$. Farther seaward, Moho remains at a constant depth of $17 \mathrm{~km}$ for another $40 \mathrm{~km}$ and the crystalline crustal thickness in this zone is $9 \mathrm{~km}$. This compares to a Moho depth of $15 \mathrm{~km}$ along the thinned Baffin Island crust on line 1 where the crystalline crustal thickness is $8 \mathrm{~km}$. The nonvolcanic character on line E96-5 but similar crustal necking profile supports an initial nonvolcanic margin in the region sampled by line 1 .

[42] The late volcanic overprint of the Baffin Island margin is most likely related to the Greenland-Iceland plume. Coincidence between the SDRs/oceanic crust and the positive gravity anomaly between 115 and $180 \mathrm{~km}$ (Figure 12) suggests that this volcanism continues for another $160 \mathrm{~km}$ to the south of line 1 , where this gravity

Figure 13. (top) Magnetic anomaly map and (bottom) gravity anomaly map. Offshore areas are represented by free-air gravity and onshore areas by Bouguer gravity. Magnetic data are taken from Oakey et al. [2001c], and gravity data are taken from Oakey et al. [2001b]. Bold solid lines show the location of the NUGGET refraction seismic experiment. Positions of ocean bottom seismometers are indicated by filled white circles. Red circles filled with crosses mark the position of deep exploration wells (H, Hekja O-71; R, Ralegh N-18; G, Gjoa G-37; Q, Qulleq-1). Selected bathymetric contours are shown as solid lines. Solid white lines indicate faults and fracture zones. Solid red lines show the position of sea-floor spreading anomalies 27 and younger (after Roest and Srivastava [1989]). Bold gray lines mark the landward limit of magmatic underplating on line 1. Bold dashed lines mark the zone where oceanic crust is observed; thin dashed lines outline the graben structure on line 1. Other seismic experiments are shown by solid lines: line D1 [Keen and Barrett, 1972], line D3 [Srivastava et al., 1982], 88-R1 [Chian and Louden, 1992], line GS93 [Gohl and Smithson, 1993], 88-R2 [Chian and Louden, 1994], E96-5N [Funck et al., 2000], BGR77-6 [Chalmers and Laursen, 1995]. Abbreviations are BI, Baffin Island; Ext., Extinct; HFZ, Hudson fracture zone; Labr., Labrador; RI, Resolution Island; UFZ, Ungava fault zone. 


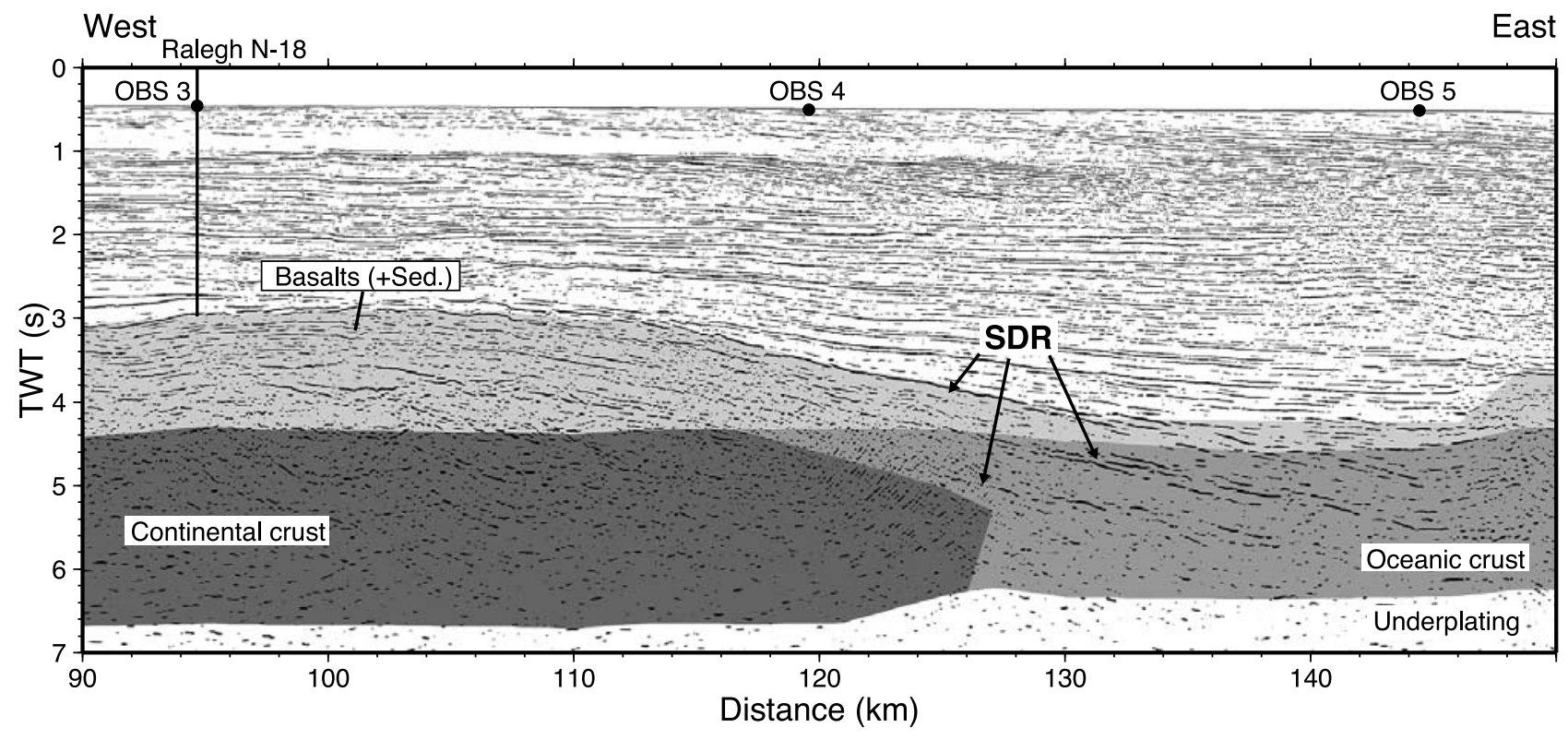

Figure 15. Subset of migrated record section from line GreenCan 2001-12A collected by TGS-NOPEC. Vertical scale is two-way travel time; horizontal scale is the distance along the velocity model of line 1 (Figure 11). Shaded areas represent crustal types as observed in the velocity model and where obtained from time conversion of layer boundaries. Filled circles indicate the location of OBS (OBS 5 was not recovered). The vertical solid line shows the location and penetration of well Ralegh N-18. Abbreviations are SDR, seaward dipping reflectors; Sed., Sediments.

signature disappears (Figure 13). On the Greenland side of Labrador Sea, SDRs are only reported from BGR line 77-6 [Chalmers and Laursen, 1995] in the vicinity of the crossing point with line 2 of our experiment (Figures 2 and 13). This shows that volcanism on either side of Labrador Sea is restricted to the northernmost area, which is consistent with the mantle plume model presented by Nielsen et al. [2002]. In this model, large-scale melting associated with active spreading restricted the southward flow of plume material to the adjacent margins of the northernmost Labrador Sea.

[43] Our results also allow the continent-ocean transition in NW Labrador Sea to be better defined. In the area of line 1 and to the south in the Saglek Basin, Skaarup et al. [2006] used the short-wavelength positive gravity anomaly at the western end of line 1 as an approximation for the continent-ocean transition (Figure 13). Skaarup et al. [2006] dismissed the stronger and wider gravity anomaly farther seaward (between OBS 4 and 6) as a possible continentocean transition because they associated this anomaly with a prograding sediment wedge observed in reflection seismic data. However, our velocity and gravity model (Figures 11 and 12) clearly associate this gravity anomaly with oceanic crust, whereas continental crust is encountered to the west of the anomaly (around OBS 4). With this definition, the continent-ocean transition in northern Labrador Sea is located $120 \mathrm{~km}$ farther seaward compared to Skaarup et al. [2006].

\subsection{Transform Fault Zone (185 to $255 \mathrm{~km})$}

[44] The oceanic crust between 185 and $255 \mathrm{~km}$ (Figure 11) coincides with the Ungava fault zone (UFZ). To the west, this segment of the oceanic crust is bounded by a graben. The sedimentation pattern across the eastern bounding fault of the graben changes significantly, with very prominent eastward dipping and convergent reflectivity in the UFZ (Figure 14). To the east, the oceanic crust terminates at $255 \mathrm{~km}$ against continental crust. The boundary between these two crustal types is gently westward dipping (Figure 16) with the oceanic crust partly overlying the continental crust, which may be related to transpressional movement along the UFZ. The downwarping of the continental crust between 230 and $300 \mathrm{~km}$ (between OBS 9 and 13, Figure 13) adjacent to the boundary could be an indication of the transpression. Both the continental and oceanic crust in this region are covered by a $4.5-\mathrm{km} / \mathrm{s}$ basalt layer that is interbedded with sediments [Klose et al., 1982], and by a $5.4-\mathrm{km} / \mathrm{s}$ layer that fills the $30-\mathrm{km}$-wide basin between the oceanic and continental crust (between 250 and $280 \mathrm{~km}$ in the model). The composition of the $5.4-\mathrm{km} / \mathrm{s}$ layer is uncertain. Its velocity is similar to oceanic layer 2 within the eastern UFZ. However, on the MCS record section (Figure 16), layer 2 is almost reflection-free while abundant internal reflectivity is observed in the $5.4-\mathrm{km} / \mathrm{s}$ layer. The reflectivity in the $5.4-\mathrm{km} / \mathrm{s}$ layer is indeed very similar to the pattern found within the overlying mixed basalt/sediment unit. Therefore we favor a similar composition with an infill of basalts and sediments in this 9-km-deep basin.

[45] The oceanic crust within the UFZ has a prominent signature in the potential field data. Figures 11 and 13 show a positive magnetic anomaly with an amplitude of $240 \mathrm{nT}$ in the western part of the UFZ. This positive anomaly is flanked by negative anomalies to either side. In the magnetic anomaly map (Figure 13), this pattern can be traced for another $200 \mathrm{~km}$ to the north, where the signal is interrupted and the correlation is more uncertain. The width of the zone with the characteristic anomaly pattern (low-high-low) 


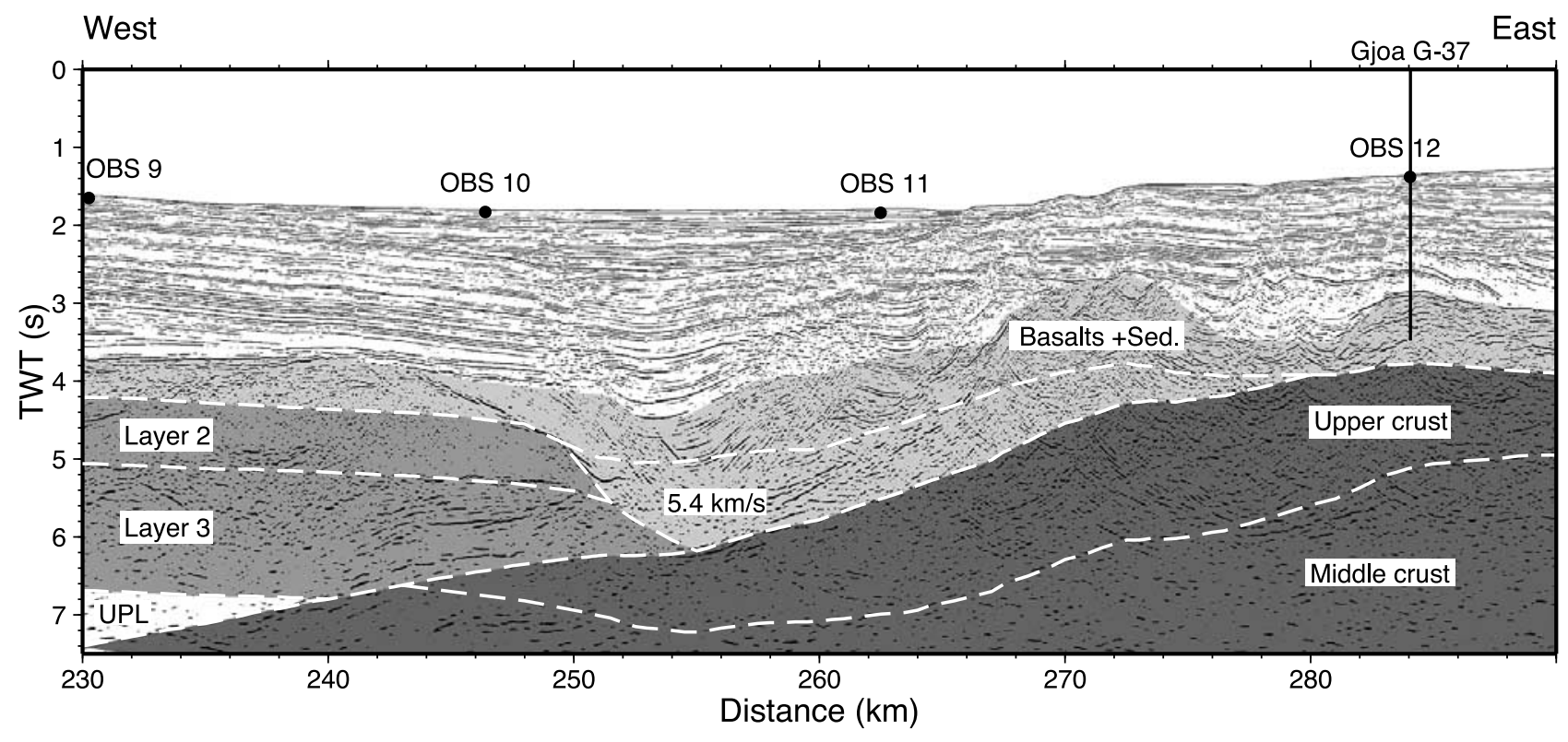

Figure 16. Subset of migrated record section from line GreenCan 2001-12A collected by TGS-NOPEC. Vertical scale is two-way travel time; horizontal scale is the distance along the velocity model of line 1 (Figure 11). Shaded areas represent crustal types as observed in the velocity model and where obtained from time conversion of layer boundaries. Dashed white lines are layer boundaries defined from line 1. Filled circles indicate the location of OBS. The vertical solid line shows the location and penetration of well Gjoa G-37. Abbreviations are Sed., Sediments; UPL, underplated layer.

between OBS 6 and 10 narrows northward, which probably indicates that the width of oceanic crust within the UFZ decreases to the north.

[46] The free-air gravity within the UFZ is characterized by a positive anomaly (42 mgal) in the west and a negative anomaly ( $-42 \mathrm{mgal}$ ) in the east (Figure 12). The minimum of the negative anomaly occurs at the contact between the oceanic and continental crust and is related to the deepening of the upper and middle continental crust in that zone and to the continental crust partly underlying the oceanic crust. The negative gravity anomaly disappears about $80 \mathrm{~km}$ to the north of line 1 (Figure 13), which suggests that the crustal geometry across the eastern limit of the UFZ changes at this position. The positive gravity anomaly continues $250 \mathrm{~km}$ into Davis Strait along a NNE trend before a bend shifts the anomaly $25 \mathrm{~km}$ closer toward Baffin Island. Here the anomaly locally interferes with another positive gravity anomaly that follows the coast of Baffin Island. This anomaly has similar characteristics to the positive gravity anomaly that lies just off Greenland and corresponds to the slope anomaly where initial crustal thinning is observed (Figures 12 and 13).

[47] Given the correlation with the potential field data, oceanic crust within the UFZ continues for at least 200 to $250 \mathrm{~km}$ to the north of line 1 . This suggests that the Davis Strait transform margin locally went through transtensional phases that created gaps between the Canadian and Greenlandic continental crust. These gaps were then filled with melt that formed the oceanic crust. In this sense the UFZ acted as leaky transform fault as originally suggested by Storey et al. [1998]. However, Storey et al. [1998] link the Early Eocene volcanism in West Greenland to net extension on the UFZ, caused by a change in regional plate kinematics as the North Atlantic opened at $\sim 55 \mathrm{Ma}$. In contrast, the basalts drilled at the Gjoa G-37 well (Figure 8) were dated at $59.5 \mathrm{Ma}$ [Williamson et al., 2001] some $30 \mathrm{~km}$ to the east of the oceanic crust in the UFZ. Even though the discontinuous reflectivity of the basalts at the Gjoa well prevent a direct correlation of basalt flows into the UFZ (Figure 16), the continuity of the $4.5 \mathrm{~km} / \mathrm{s}$-basalt layer from the well into the UFZ suggests a similar age of the basalts and would argue for Paleocene rather than Eocene transtension within the southern UFZ. Basalts drilled at the Hekja well are also of Paleocene age [Sønderholm et al., 2003], showing the widespread occurrence of Paleocene basalts in southern Davis Strait.

\subsection{Magmatic Underplating (40 to $430 \mathrm{~km}$ )}

[48] A high-velocity layer $(7.4 \mathrm{~km} / \mathrm{s})$ at the base of the crust was observed along the central part of line 1 (Figure 11) and is interpreted as magmatic underplating related to the Greenland-Iceland plume. Paleocene volcanic rocks in the Davis Strait region are thought to mark the arrival of the plume in the study area [Storey et al., 1998] and several studies assume the plume track beneath Greenland [Morgan, 1983; Forsyth et al., 1986; Lawver and Müller, 1994]. It is interesting to note that the underplating is restricted to areas with thinnest crust (both oceanic and continental crust). This is consistent with the model of Sleep [1997] in which buoyant plume material ponds at the base of the lithosphere and then flows laterally and preferentially along thin lithosphere. In the example of line 1, material from the Greenland-Iceland plume arrived in the Davis Strait region and was then channeled southwards beneath the thinned lithosphere in the central part of the strait.

[49] Nielsen et al. [2002] modeled the flow of the plume material. In this model, active spreading restricted the 


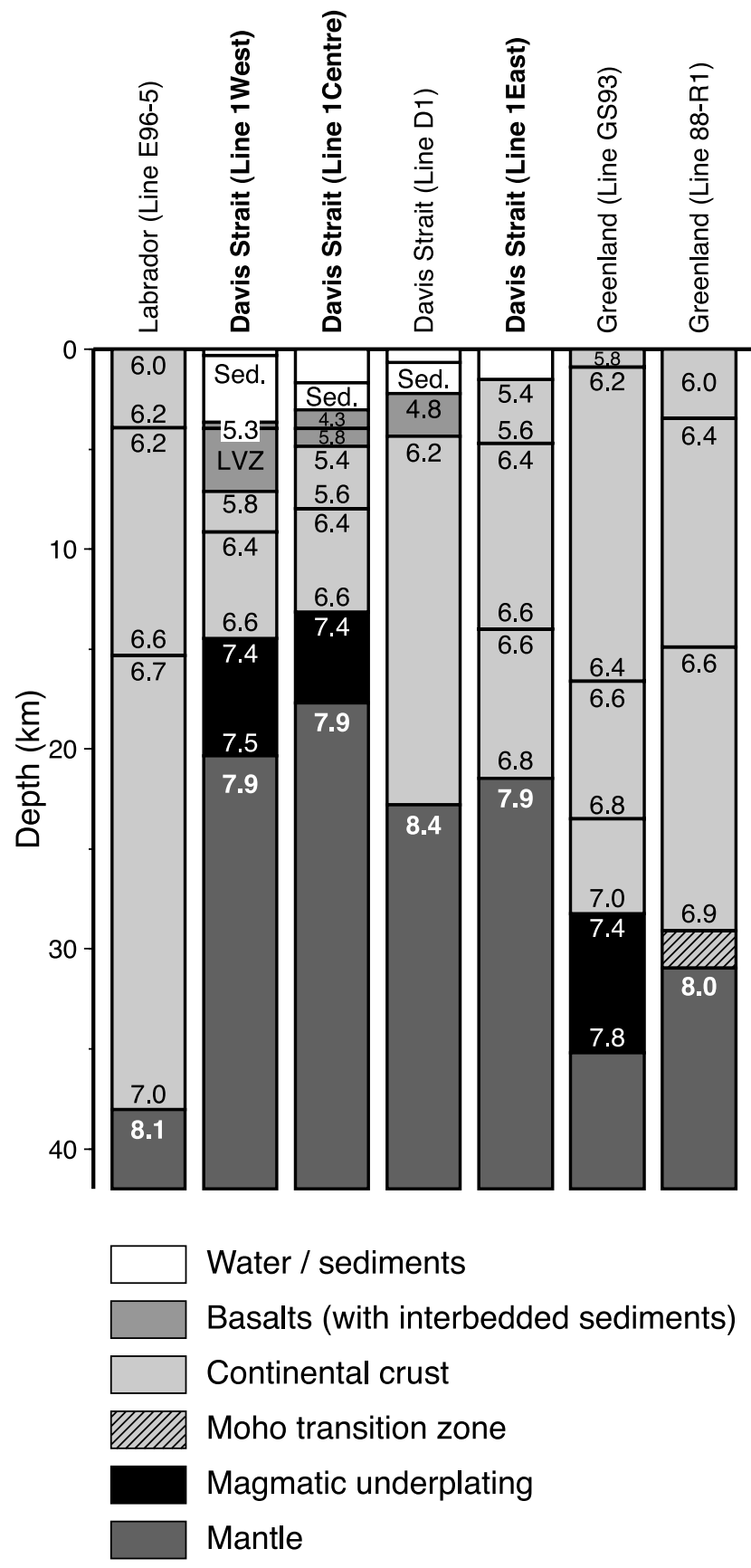

Figure 17. Comparison of velocity profiles from line 1 with other data from the Archean North Atlantic craton. Profiles are taken from line 1 (Figure 11), line E96-5 [Funck and Louden, 1999], line D1 [Keen and Barrett, 1972], line GS93 [Gohl and Smithson, 1993], and line 88-R1 [Chian and Louden, 1992]. For location of the lines see Figures 1 and 2. Abbreviations are LVZ, low velocity zone; Sed., Sediments.

channeled, southward flow of plume material to the northernmost $100-200 \mathrm{~km}$ in Labrador Sea. This is in agreement with our observations, that a volcanic-style margin is encountered on line 1 off SE Baffin Island but not in NE Labrador [Funck and Louden, 1999]. The same applies to the Greenland side of the margin, where seaward dipping reflectors have only been observed immediately to the south of line 1 (BGR line 77-6). The model of Nielsen et al. [2002] also predicts the thickness of excess igneous crust produced from melting of the plume material. In the Davis Strait region and northern Labrador Sea, $5 \mathrm{~km}$ of excess crust is predicted. The thickness of the underplated layer on line 1 varies generally between 4 and $8 \mathrm{~km}$ with an average thickness of $5 \mathrm{~km}$, which is a good match with the model of Nielsen et al. [2002].

[50] Immediately to the east of line 1, another wide-angle seismic line (line GS93, Figures 2 and 17) runs parallel to the coast of Greenland. The velocity model for this line shows a 3 to $8-\mathrm{km}$ thick layer with velocities of $7.4-$ $7.8 \mathrm{~km} / \mathrm{s}$ at the base of the crust [Gohl and Smithson, 1993]. Gohl and Smithson [1993] interpret this layer as an underplated mafic to ultramafic zone that is related to the magmatism in Davis Strait. These results are difficult to reconcile with our observations from line 1 because our model lacks an underplated layer on the Greenland side. In the channeling models of Sleep [1997] and Nielsen et al. [2002], little or no plume material is predicted beneath the thick Archean lithosphere where line GS93 is located.

[51] There are three possible explanations for this discrepancy:

[52] 1. The high-velocity layer on line GS93 is not related to the Paleocene and Eocene magmatism in Davis Strait but to an older event. We have some doubt about this possibility because Archean crust is generally characterized by the absence of a basal high-velocity layer due to the refractory nature of the lithospheric mantle that is ultradepleted in FeO [Durrheim and Mooney, 1994]. Other refraction seismic studies within the North Atlantic craton in West Greenland [Chian and Louden, 1992] and in Labrador [Funck and Louden, 1998, 1999] show no evidence for underplating; the same is true for the Archean crust in NW Greenland [Jackson and Reid, 1994; Reid and Jackson, 1997; Funck et al., 2006].

[53] 2. The velocity model of line 1 (Figure 11) is wrong and an underplated layer was missed beneath Greenland. This possibility cannot be fully excluded, but observed $P_{n}$ phases on OBS 21 and 22 (Figure 4) would be difficult to model with underplating beneath Greenland and the fit of the gravity model would worsen.

[54] 3. The underplating in the model of Gohl and Smithson [1993] is incorrectly interpreted. Despite the careful modeling that was carried out, we think that the design of the experiment has some potential pitfalls that were not fully considered. The airgun shots parallel to the coast were recorded by onshore seismometers that were 20-35 km away from the shot line. Crustal thinning can be expected within this $35-\mathrm{km}$-wide zone of the continental margin and it is possible that side echoes (out of plane reflections) from the Moho could create the observed double reflection that was interpreted as a reflection from the top and bottom of the underplated layer. Unless this side echo possibility can be excluded, the underplating on line GS93 should be treated with some caution.

\subsection{Continental Crust (0 to $120 \mathrm{~km} ; 240$ to $630 \mathrm{~km}$ )}

[55] Our velocity model along line 1 shows that most of the crust is of continental character with the exception of the UFZ and a $60-\mathrm{km}$-wide zone adjacent to the Canadian margin where crust with a signature typical for oceanic 
crust is encountered. This is an important result of the survey because it resolves the previous controversy regarding the nature of the crust in Davis Strait.

\subsubsection{Crustal Character in Davis Strait}

[56] Tucholke and Fry [1985] suggested from their detailed map of basement structure in the NW Atlantic Ocean that most of the crust in Davis Strait is oceanic in origin. This includes the central part of line 1 around the Gjoa well, which we interpret to be continental. In this zone (255 to $410 \mathrm{~km}$ in the model), 8 to $12-\mathrm{km}$-thick crust is observed with a two-layered structure $(5.4-5.6 \mathrm{~km} / \mathrm{s}$ and $6.4-$ $6.6 \mathrm{~km} / \mathrm{s}$ ) that corresponds to the velocities found in the upper and middle crust off Greenland. The change from thin continental crust in the centre part of the line to $20-\mathrm{km}$-thick crust off Greenland occurs at a steep fault at $425 \mathrm{~km}$ (Figures 11 and 14) where the basement depth changes from $6 \mathrm{~km}$ to $2 \mathrm{~km}$. At the same position, a significant change in the magnetic pattern can be observed as well. Positive magnetic anomalies up to $550 \mathrm{nT}$ characterize the thick crust off Greenland, while the magnetic pattern is much more subdued over the thin continental crust in the centre of the line with anomalies varying between -158 and 192 nT. High amplitude positive magnetic anomalies are also found in West Greenland to the NE of line 1 (Figure 13).

[57] The prominent positive magnetic anomaly pattern on the eastern part of line 1 continues to the north into central Davis Strait up to refraction seismic line D1 (Figure 13). The velocity structure obtained for line D1 (Figure 17) shows a Moho depth of $22 \mathrm{~km}$ and an 18-km-thick major crustal layer with a velocity of $6.2 \mathrm{~km} / \mathrm{s}$ covered by a $2-\mathrm{km}-$ thick layer with a velocity of $4.8 \mathrm{~km} / \mathrm{s}$. Originally, Keen and Barrett [1972] interpreted the $4.8-\mathrm{km} / \mathrm{s}$ layer as the equivalent to oceanic layer 2 and concluded that the crust in Davis Strait is composed of oceanic crustal material. Later, Keen et al. [1974] modified this interpretation and suggested a mixed crustal composition with fragments of continental crust and plume related rocks. Chalmers and Pulvertaft [2001] suggest that the velocity profile along line D1 is consistent with continental crust underlying the strait. This is also our preferred interpretation. We associate the $4.8-\mathrm{km} / \mathrm{s}$ layer with the products of numerous Paleocene and Eocene magmatism in Davis Strait. Reflection seismic mapping shows that line D1 lies within the basalt-covered zone off Baffin Island [Skaarup et al., 2006]. Also the velocity of $4.8 \mathrm{~km} / \mathrm{s}$ is compatible with the velocities observed within the volcanics of line $1(4.3-4.9 \mathrm{~km} / \mathrm{s})$. The thickness of the major crustal layer on line D1 compares very well with the crust in the eastern part of line 1 and given the previously described correlation with the magnetic pattern, a continental composition of the crust on line $\mathrm{D} 1$ is the most plausible interpretation. This is also because line D1 lies to the east of potential field anomalies associated with possible oceanic crust in the UFZ (Figure 13). The misfit between the crustal velocities on line D1 $(6.2 \mathrm{~km} / \mathrm{s})$ and off Greenland on line $1(5.4-6.8 \mathrm{~km} / \mathrm{s})$ may be an artifact of poorer resolution for line D1, with just two receivers $38 \mathrm{~km}$ apart. Indeed, the crustal velocity structure on line D1 does not fit with any part of line 1 , neither with oceanic nor with continental segments (Figure 17).

[58] In summary, on the basis of the results from line 1 (Figure 11) and the potential field data (Figure 13), there is no evidence for oceanic crust in central and southern Davis Strait other than in areas where the UFZ has acted as a leaky transform fault. In northern Davis Strait, Chalmers and Pulvertaft [2001] exclude oceanic crust in the east, while extensive Paleogene basalts mask the crust in the west.

\subsubsection{Comparison of the Continental Crust With}

\section{Other Studies}

[59] The velocity model for line 1 (Figure 11) shows differences between the continental crust of Canada and Greenland. Off SE Baffin Island, two crustal layers with velocities between 5.8 and $6.6 \mathrm{~km} / \mathrm{s}$ were identified, while off Greenland, the crust is divided into three layers (5.4$6.8 \mathrm{~km} / \mathrm{s}$ ). On the Canadian side of the profile, the twolayered crustal structure is probably an artifact of the data coverage, which is limited to the thinned portions of the crust and likely fails to sample the lowermost crustal layer. The velocities $(6.4-6.6 \mathrm{~km} / \mathrm{s})$ labeled as lower crust on the Canadian side are similar to the midcrustal velocities off Greenland (6.4-6.6 km/s). Full crustal thickness of the Archean North Atlantic craton in northernmost Labrador is around $38 \mathrm{~km}$ [Funck et al., 2000; Funck and Louden, 1999], while the maximum crustal thickness on line 1 within the area of ray coverage is $11 \mathrm{~km}$. This indicates that there is space for another crustal layer farther landward.

[60] The observed crustal velocities of 5.8 to $6.6 \mathrm{~km} / \mathrm{s}$ off Baffin Island are similar to upper-crustal and midcrustal velocities of 6.0 to $6.6 \mathrm{~km} / \mathrm{s}$ found in northern Labrador [Funck and Louden, 1999] (Figure 17). The full-thickness upper crust onshore has slightly higher velocities than on line 1 and lacks a velocity contrast across the two uppermost layers. This difference may reflect effects associated with the crustal extension, where faulting potentially can reduce seismic velocities or produce detachment layers. In summary, the crustal velocity structure on the western end of line 1 is consistent with Archean crust found elsewhere in Labrador, with the caveat that we did not fully image the lower crustal layer at the western end of line 1 .

[61] The upper crustal velocities differ on either side of line 1: $5.8-6.1 \mathrm{~km} / \mathrm{s}$ is observed off $\mathrm{SE}$ Baffin Island compared with $5.4-5.6 \mathrm{~km} / \mathrm{s}$ off Greenland (Figure 11). The low velocities on the Greenland side do not match with other observations from the Archean North Atlantic craton. There are two other refraction seismic lines within the Archean zone in Greenland (Figure 2). On line GS93 [Gohl and Smithson, 1993], upper crustal velocities are $5.8 \mathrm{~km} / \mathrm{s}$ while they are $6.0 \mathrm{~km} / \mathrm{s}$ on line 88-R1 [Chian and Louden, 1992] (Figure 17). The geological map of Greenland [Escher and Pulvertaft, 1995] shows that the dominant rock type within the North Atlantic craton is gneiss. However, in the area to the east of line 1 a number of Archean granitic intrusions are found (Qôrqut granite). Velocities within the widespread granitic intrusions in southern Greenland are $5.6 \mathrm{~km} / \mathrm{s}$ on line 88-R1 [Chian and Louden, 1992] and $5.4 \mathrm{~km} / \mathrm{s}$ on line 88-R2 [Chian et al., 1995b] (Figure 2). We therefore suggest that the upper crustal velocities of $5.4 \mathrm{~km} / \mathrm{s}$ on the Greenland side of line 1 are related to granitic intrusions. It is unclear if the positive magnetic anomalies in the offshore area east of OBS 19 (Figure 13) relate to this intrusion because the anomalies onshore correlate only partly with the exposed Qôrqut granites. Middle and lower crustal velocities on the eastern end of line 1 are compatible with velocities found elsewhere in the North 
Atlantic craton (Figure 17) with the exception of the modeled underplating on line GS93, as discussed above in section 5.5 (Magmatic Underplating).

\section{Conclusions}

[62] The seismic transect across southern Davis Strait provides new insights into the structure and evolution of this transform margin. The most important result is certainly that most of the crust underlying the Davis Strait region is of continental character. Paleogene volcanism associated with the Greenland-Iceland plume is found on the western part of the transect. The maximum thickness of the basalt unit is $4 \mathrm{~km}$ but it also contains interbedded sediment layers and probably Cretaceous and older sediments underneath, which cannot be resolved by the refraction seismic method due to velocity inversions.

[63] Oceanic crust is encountered within a $60-\mathrm{km}$ wide zone of the Ungava Fault Zone (UFZ), the major transform fault system along which the seafloor spreading in Labrador Sea was transferred through Davis Strait into Baffin Bay. The occurrence of oceanic crust is consistent with the idea of Storey et al. [1998] that the UFZ acted as leaky transform fault. Hence we think that the movement along the fault was not pure strike-slip but also characterized by phases of transtension during which gaps in the thin continental crust were filled with melt that formed new oceanic crust. Potential field maps (Figure 13) associate the UFZ with positive magnetic and gravity anomalies that can be traced for $200-300 \mathrm{~km}$ farther to the north of our transect. This suggests that the narrow zone of oceanic crust within the UFZ probably extends farther to the north.

[64] Magmatic underplating at the base of the crust exists across the centre part of the line where thin crust is encountered. The underplating is thought to be related to the southward spreading of plume material in Davis Strait guided by relief in the lithosphere along which the material was channeled [cf. Sleep, 1997; Nielsen et al., 2002]. Hence ample hot mantle material was available from which melt could have been extracted to feed the leaky transform fault in Davis Strait. The average thickness of the underplated layer is $5 \mathrm{~km}$, which corresponds to predictions from the plume model of Nielsen et al. [2002].

[65] In contrast to the nonvolcanic margins farther to the south [Chian et al., 1995a, 1995b; Chalmers and Pulvertaft, 2001], margins in northernmost Labrador Sea have been affected by volcanism. Seaward-dipping reflectors (SDR) are known from the Greenland margin to the south of line 1 [Chalmers and Laursen, 1995]. On the Labrador side our transect shows a margin with oceanic crust, underplating, and SDRs. However, the thinning of the continental crust is similar to a profile farther south (line E96-5 [Funck and Louden, 1999]) where the margin is nonvolcanic. Therefore the volcanism on line 1 is interpreted as a late volcanic overprint of a margin that went through a prolonged nonvolcanic rifting phase in the Cretaceous until the Paleogene when the Greenland-Iceland plume affected this area.

[66] Line 1 also can help define the continent-ocean transition in the Saglek Basin. The transition was controversial in this area because a positive gravity anomaly (slope anomaly) off Labrador splits into two branches in the Saglek Basin. Our data show that thin continental crust extends out to the seaward anomaly around OBS 4, which is $120 \mathrm{~km}$ farther to the east than the landward gravity anomaly.

[67] Acknowledgments. We thank all personnel onboard the CCGS Hudson who helped to collect the seismic data in the extreme weather conditions encountered during the survey. We are grateful to Jens Christian Olsen from TGS-NOPEC for providing the coincident reflection seismic data along our transect and for the permission to show the data. Gordon Oakey provided the potential field and physiography data in digital format. We thank Trine Dahl-Jensen for her comments on the manuscript. Reviews from John Hopper, Wilfried Jokat, and Allegra Hosford Scheirer helped improve the manuscript. The work was funded by the Danish National Research Foundation (Danmarks Grundforskningsfond), the National Sciences and Engineering Research Council of Canada, and by the NEON (New Energy Options for Northerners) program of the Geological Survey of Canada. Part of the OBS operation was supported by IFREMER and by the European Union through a grant for the "Access to Large Scale Facilities" at GEOMAR, Kiel, Germany (HPRI-CT-2001-00154). The paper is published with the permission of the Geological Survey of Denmark and Greenland. Geological Survey of Canada contribution 20060165 .

\section{References}

Balkwill, H. R. (1987), Labrador Basin: structural and stratigraphic style, in Sedimentary Basins and Basin-Forming Mechanisms, edited by C. Beaumont and A. J. Tankard, Mem. Can. Soc. Pet. Geol., 12, $17-43$.

Chalmers, J. A. (1997), The continental margin off southern Greenland: Along-strike transition from an amagmatic to a volcanic margin, J. Geol. Soc., 154, 571-576.

Chalmers, J. A., and K. H. Laursen (1995), Labrador Sea: the extent of continental and oceanic crust and the timing of the onset of seafloor spreading, Mar. Petrol. Geol., 12, 205-217, doi:10.1016/ 0264-8172(95)92840-S.

Chalmers, J. A., and T. C. R. Pulvertaft (2001), Development of the continental margins of the Labrador Sea: A review, in Nonvolcanic Rifting of Continental Margins: A Comparison of Evidence From Land and Sea, edited by R. C. L. Wilson et al., Spec. Publ. Geol. Soc., 187, 77-105.

Chian, D., and K. Louden (1992), The structure of Archean-Ketilidian crust along the continental shelf of southwestern Greenland from a seismic refraction profile, Can. J. Earth Sci., 29, 301-313.

Chian, D., and K. E. Louden (1994), The continent-ocean crustal transition across the southwest Greenland margin, J. Geophys. Res., 99, 91179135

Chian, D., C. Keen, I. Reid, and K. E. Louden (1995a), Evolution of nonvolcanic rifted margins: New results from the conjugate margins of the Labrador Sea, Geology, 23, 589-592.

Chian, D., K. E. Louden, and I. Reid (1995b), Crustal structure of the Labrador Sea conjugate margin and implications for the formation of nonvolcanic continental margins, J. Geophys. Res., 100, 24,239-24,253.

Durrheim, R. J., and W. D. Mooney (1994), Evolution of the Precambrian lithosphere: seismological and geochemical constraints, J. Geophys. Res., 99, 15,359-15,374

Escher, J. C., and T. C. R. Pulvertaft (1995), Geological map of Greenland, scale 1:2.500.000, Geol. Surv. of Greenland, Copenhagen, Denmark.

Forsyth, D. A., I. P. Morel-à-L'Huissier, I. Asudeh, and A. G. Green (1986),

Alpha Ridge and Iceland - Products of the same plume?, J. Geodyn., 6, 197-214, doi:10.1016/0264-3707(86)90039-6.

Funck, T., and K. E. Louden (1998), Wide-angle seismic imaging of pristine Archean crust in the Nain Province, Labrador, Can. J. Earth. Sci., 35, $672-685$.

Funck, T., and K. E. Louden (1999), Wide-angle seismic transect across the Torngat Orogen, northern Labrador: Evidence for a Proterozoic crustal root, J. Geophys. Res., 104, 7463-7480.

Funck, T., K. E. Louden, R. J. Wardle, J. Hall, J. W. Hobro, M. H. Salisbury, and A. M. Muzzatti (2000), Three-dimensional structure of the Torngat Orogen (NE Canada) from active seismic tomography, J. Geophys. Res., 105, 23,403-23,420.

Funck, T., H. R. Jackson, S. A. Dehler, and I. D. Reid (2006), A refraction seismic transect from Greenland to Ellesmere Island, Canada: The crustal structure in southern Nares Strait, Polarforschung, 74, 94-112.

Gohl, K., and S. B. Smithson (1993), Structure of Archean crust and passive margin of southwest Greenland from seismic wide-angle data, J. Geophys. Res., 98, 6623-6638.

Holbrook, W. S., G. M. Purdy, R. E. Sheridan, L. Glover III, M. Talwani, J. Ewing, and D. Hutchinson (1994a), Seismic structure of the U. S. MidAtlantic continental margin, J. Geophys. Res., 99, 17,871-17,891. 
Holbrook, W. S., E. C. Reiter, G. M. Purdy, D. Sawyer, P. L. Stoffa, J. A Austin, J. Oh, and J. Makris (1994b), Deep structure of the U. S. Atlantic continental margin, offshore North Carolina, from coincident oceanbottom and multichannel seismic data, J. Geophys. Res., 99, 9155-9178.

Holbrook, W. S., et al. (2001), Mantle thermal structure and active upwelling during continental breakup in the North Atlantic, Earth Planet. Sci. Lett., 190, 251-266, doi:10.1016/S0012-821X(01)00392-2.

Hopper, J. R., T. Dahl-Jensen, W. S. Holbrook, H. C. Larsen, D. Lizarralde, J. Korenaga, G. M. Kent, and P. B. Kelemen (2003), Structure of the SE Greenland margin from seismic reflection and refraction data: Implications for nascent spreading center subsidence and asymmetric crustal accretion during North Atlantic opening, J. Geophys. Res., 108(B5), 2269, doi:10.1029/2002JB001996.

Jackson, H. R., and I. Reid (1994), Crustal thickness between the Greenland and Ellesmere Island margins determined from seismic refraction, Can. J. Earth Sci., 31, 1407-1418.

Jackson, H. R., T. Funck, P. Girouard, B. Chapman, F. Klingelhöfer, J. Gerlings, and A. Jensen (2003), Cruise report Hudson 2003-047 NUGGET (Nunavut to Greenland Geophysical Transect), Open File Rep. 1838, 157 pp., Geol. Surv. of Can., Dartmouth, Nova Scotia, Canada.

Keen, C. E., and D. L. Barrett (1972), Seismic refraction studies in Baffin Bay: An example of a developing ocean basin, Geophys. J. R. Astron. Soc., 30, 253-271.

Keen, C. E., M. J. Keen, D. I. Ross, and M. Lack (1974), Baffin Bay: Small ocean basin formed by sea-floor spreading, AAPG Bull., 58, 1089-1108.

Kerr, J. W. (1967), A submerged continental remnant of the Labrador Sea, Earth Planet. Sci. Lett., 2, 283-289, doi:10.1016/0012$821 \times(67) 90143-4$

Klose, G. W., E. Malterre, N. J. McMillan, and C. G. Zinkan (1982), Petroleum exploration offshore southern Baffin Island, northern Labrador Sea, Canada, in Arctic Geology and Geophysics, edited by A. F. Embry and H. R. Balkwill, Mem. Can. Soc. Pet. Geol., 8, 233-244.

Larsen, H. C., and A. D. Saunders (1998), Tectonism and volcanism at the southeast Greenland rifted margin: A record of plume impact and later continental rupture, in Proceedings of the Ocean Drilling Program, Scientific Results, vol. 152, pp. 503-533, Ocean Drill. Program, College Station, Tex

Lawver, L. A., and R. D. Müller (1994), Iceland hotspot track, Geology, 22, $311-314$.

Ludwig, W. J., J. E. Nafe, and C. L. Drake (1970), Seismic refraction, in The Sea, vol. 4, New Concepts of Sea Floor Evolution, Part I, edited by A. E. Maxwell, pp. 53-84, Wiley-Interscience, Hoboken, N. J.

Lutter, W. J., and R. L. Nowack (1990), Inversion for crustal structure using reflections from the PASSCAL Ouachita experiment, J. Geophys. Res., 95, 4633-4646.

Morgan, W. J. (1983), Hotspot tracks and the early rifting of the Atlantic, Tectonophysics, 94, 123-139, doi:10.1016/0040-1951(83)90013-6.

Nielsen, T. K., H. C. Larsen, and J. R. Hopper (2002), Contrasting rifted margin styles south of Greenland: implications for mantle plume dynamics, Earth Planet. Sci. Lett., 200, 271-286, doi:10.1016/S0012 821X(02)00616-7.

Oakey, G. N., S. Ekholm, H. R. Jackson, and C. Marcussen (2001a), Physiography, Davis Strait region, Canadian and Greenland Arctic, Open File Rep. 3933B, Geol. Surv. of Can., Ottawa, Ontario, Canada.

Oakey, G. N., R. Forsberg, and H. R. Jackson (2001b), Gravity anomaly map, Bouguer on land, free air at sea, Davis Strait region, Canadian and Greenland Arctic, Open File Rep. 3934B, Geol. Surv. of Can., Ottawa, Ontario, Canada.

Oakey, G. N., W. Miles, and H. R. Jackson (2001c), Magnetic anomaly map, Davis Strait region, Canadian and Greenland Arctic, Open File Rep. 3935B, Geol. Surv. of Can., Ottawa, Ontario, Canada.
Pearson, D. G., C. H. Emeleus, and S. P. Kelley (1996), Precise ${ }^{40} \mathrm{Ar} /{ }^{39} \mathrm{Ar}$ age for the initiation of Palaeogene volcanism in the Inner Hebrides and its regional significance, J. Geol. Soc. London, 153, 815-818.

Reid, I., and H. R. Jackson (1997), Crustal structure of northern Baffin Bay: Seismic refraction results and tectonic implications, J. Geophys. Res., $102,523-542$.

Roest, W. R., and S. P. Srivastava (1989), Sea-floor spreading in the Labrador Sea: A new reconstruction, Geology, 17, 1000-1003.

Skaarup, N., H. R. Jackson, and G. Oakey (2006), Margin segmentation of Baffin Bay/Davis Strait, eastern Canada based on seismic reflection and potential field data, Mar. Petrol. Geol., 23, 127-144, doi:10.1016/ j.marpetgeo.2005.06.002.

Sleep, N. H. (1997), Lateral flow and ponding of starting plume material, J. Geophys. Res., 102, 10,001-10,012.

Sønderholm, M., H. Nøhr-Hansen, J. Bojesen-Koefoed, F. Dalhoff, and J. A. Rasmussen (2003), Regional correlation of Mesozoic-Palaeogene sequences across the Greenland-Canada boundary, Rep. 2003/25, 175 pp., Geol. Surv. of Denmark and Greenland, Copenhagen.

Srivastava, S. P. (1978), Evolution of the Labrador Sea and its bearing on the early evolution of the North Atlantic, Geophys. J. R. Astron. Soc., 52, $313-357$.

Srivastava, S. P., B. MacLean, R. F. Macnab, and H. R. Jackson (1982), Davis Strait: structure and evolution as obtained from a systematic geophysical survey, in Arctic Geology and Geophysics, edited by A. F. Embry and H. R. Balkwill, Mem. Can. Soc. Pet. Geol., 8, 267-278.

Storey, M., R. A. Duncan, A. K. Pedersen, L. M. Larsen, and H. C. Larsen (1998), ${ }^{40} \mathrm{Ar} /{ }^{39}$ Ar geochronology of the West Greenland Tertiary volcanic province, Earth Planet. Sci. Lett., 160, 569-586, doi:10.1016/S0012$821 X(98) 00112-5$.

Talwani, M., J. L. Worzel, and M. Landisman (1959), Rapid gravity computations for two-dimensional bodies with application to the Mendocino submarine fracture zone, J. Geophys. Res., 64, 49-59.

Tucholke, B. E., and V. A. Fry (1985), Basement structure and sediment distribution in Northwest Atlantic Ocean, AAPG Bull., 69, 2077-2097.

White, R. S., D. McKenzie, and K. O'Nions (1992), Oceanic crustal thickness from seismic measurements and rare earth element inversions, J. Geophys. Res., 97, 19,683-19,715.

Williamson, M.-C., M. E. Villeneuve, L. M. Larsen, H. R. Jackson, G. N. Oakey, and B. Maclean (2001), Age and petrology of offshore basalts from the Southeast Baffin Island shelf, Davis Strait, and the Western Greenland continental margin, paper presented at Joint Annual Meeting, Geol. Assoc. of Can.-Mineral. Assoc. of Can., St. John's, Newfoundland and Labrador, Canada.

Zelt, C. A., and D. A. Forsyth (1994), Modeling wide-angle seismic data for crustal structure: southeastern Grenville Province, J. Geophys. Res., 99, 11,687-11,704.

Zelt, C. A., and R. B. Smith (1992), Seismic traveltime inversion for 2-D crustal velocity structure, Geophys. J. Int., 108, 16-34.

T. Funck, Geological Survey of Denmark and Greenland, Øster Voldgade 10, 1350 Copenhagen K, Denmark. (tf@geus.dk)

H. R. Jackson, Geological Survey of Canada (Atlantic), Bedford Institute of Oceanography, P. O. Box 1006, Dartmouth, Nova Scotia, B2Y 4A2, Canada. (rujackson@nrcan.gc.ca)

F. Klingelhöfer, Department of Geodynamciss and Geophysics, IFREMER, Centre de Brest, BP 70, 29280 Plouzané, France. (klingelhoefer@ ifremer.fr)

K. E. Louden, Department of Oceanography, Dalhousie University, Halifax, Nova Scotia, B3H 4J1, Canada. (keith.louden@dal.ca) 